DOE/NV/11718--1060

\title{
Hydrogeologic Characterization Data from the Area 5 Shallow Soil Trenches
}

\author{
Prepared by \\ Bechtel Nevada \\ Geotechnical Sciences \\ Las Vegas, Nevada \\ Prepared for \\ U.S. Department of Energy \\ National Nuclear Security Administration \\ Nevada Site Office \\ Las Vegas, Nevada
}

July 2005

\footnotetext{
This manuscript has been authored by Bechtel Nevada under Contract No. DE-AC08-96NV11718 with the U.S. Department of Energy. The United States Government retains and the publisher, by accepting the article for publication, acknowledges that the United States Government retains a non-exclusive, paid-up, irrevocable, world-wide license to publish or reproduce the published form of this manuscript, or allow others to do so, for United States Government purposes.
} 


\section{DISCLAIMER STATEMENT}

This report was prepared as an account of work sponsored by an agency of the U.S. Government. Neither the U.S. Government nor any agency thereof, nor any of their employees, nor any of their contractors, subcontractors or their employees, makes any warranty or representation, express or implied, or assumes any legal liability or responsibility for the accuracy, completeness, or usefulness of any information, apparatus, product, or process disclosed, or represents that its use would not infringe privately own rights. Reference herein to any specific commercial product, process, or service by trade name, trademark, manufacturer, or otherwise, does not necessarily constitute or imply its endorsement, recommendation, or favoring by the U.S. Government or any agency thereof. The views and opinions of authors expressed herein do not necessarily state or reflect those of the U.S. Government or any agency thereof

\section{AVAILABILITY STATEMENT}

Available for sale to the public from-

U.S. Department of Commerce

National Technical Information Service

5285 Port Royal Road

Springfield, VA, 22161-0002

Telephone: 800.553 .6847

Fax: 703.605.6900

E-mail: orders@ntis.gov

Online ordering: http://www.ntis.gov/ordering.htm

Available electronically at http://www.osti.gov/bridge.

Available for a processing fee to U.S. Department of Energy and its contractors, in paper, from-

U.S. Department of Energy

Office of Scientific and Technical Information

P.O. Box 62

Oak Ridge, TN 37831-0062

Telephone: 865.576.8401

Fax: 865.576.5728

E-mail: reports@adonis.osti.gov 


\title{
Hydrogeologic Characterization Data from the Area 5 Shallow Soil Trenches
}

\author{
Prepared for: \\ U.S. Department of Energy \\ National Nuclear Security Administration \\ Nevada Site Office \\ Las Vegas, Nevada
}

Prepared by:

Bechtel Nevada

Geotechnical Sciences

Las Vegas, Nevada

July 2005 
This page intentionally left blank. 


\section{Hydrogeologic Characterization Data from the Area 5 Shallow Soil Trenches}

\section{DOE/NV/11718--1060}

\section{Preface}

The Special Projects Section of Reynolds Electrical \& Engineering Co., Inc. (REECo), a predecessor to Bechtel Nevada (BN), was responsible for characterizing the subsurface hydrogeology of the Area 5 Radioactive Waste Management Site (RWMS) at the Nevada Test Site for the U.S. Department of Energy, Nevada Operations Office in the early 1990s. Some of this work was documented in a series of unpublished data reports. As part of BN's current scope for closure planning for the Area 5 RWMS, three of these REECo data reports have been updated to current editorial standards for approval for public release so they will be accessible for public review and for citation in future documents.

This document contains the first of the three reports. It was originally prepared under the same title by D. O. Blout and K. A. Zukosky (REECo) and K. D. Donnelson (Raytheon Services Nevada) in September 1994, and assigned the document number, DOE/NV/11432--169. The report has been updated by revising it to conform to current editorial standards of BN and of the U.S. Department of Energy, National Nuclear Security Administration Nevada Site Office. In addition, some errors in the original unreviewed and unpublished report have been corrected. 
This page intentionally left blank. 


\title{
Hydrogeologic Characterization Data from the Area 5 Shallow Soil Trenches \\ DOE/NV/11718--1060
}

\begin{abstract}
Four shallow soil trenches excavated in the vicinity of the Area 5 Radioactive Waste Management Site at the Nevada Test Site were sampled in 1994 to characterize important physical and hydrologic parameters which can affect the movement of water in the upper few meters of undisturbed alluvium. This report describes the field collection of geologic samples and the results of laboratory analyses made on these samples. This report provides only qualitative analyses and preliminary interpretations.

Based on field observations of texture, the alluvial deposits in the trenches are relatively homogeneous with respect to particle size distribution and are primarily composed of sand with silt, some gravel, and little clay. Laboratory measurements of hydrologic properties, including porosity, dry bulk density, and saturated hydraulic conductivity, are typical of sandy, near-surface alluvial materials. Water content values are low, constant, and consistent between trenches. Inorganic and organic carbon concentrations are low and constant within and between trenches. The physical and hydrological properties data indicate that the near-surface alluvial deposits can be considered as homogeneous material.
\end{abstract}

Using ratio of chlorine-36 to chlorine as an environmental tracer provides evidence that very little downward flow of liquid water is occurring in the near-surface portion of the vadose zone. 
This page intentionally left blank. 


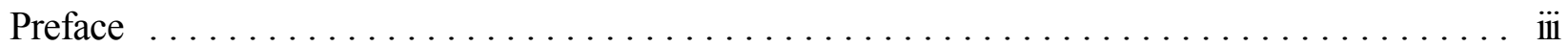

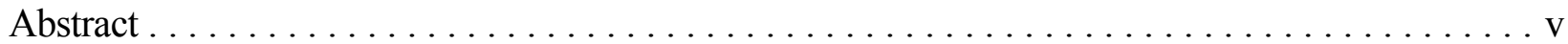

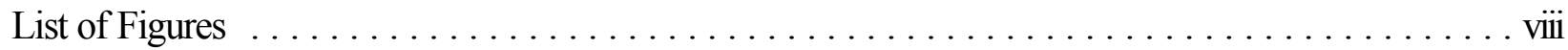

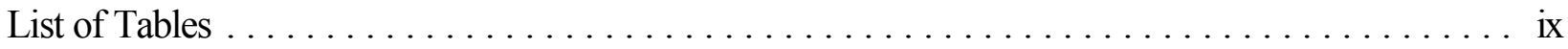

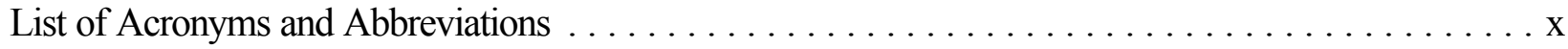

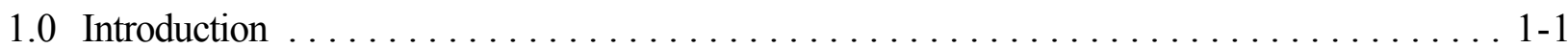

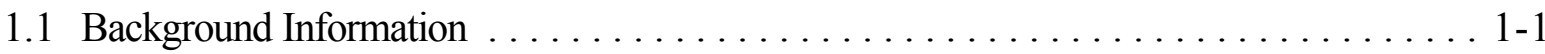

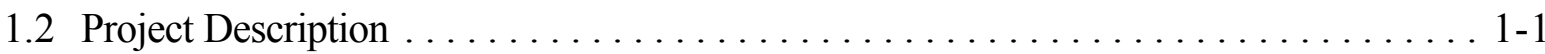

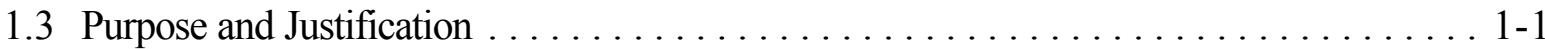

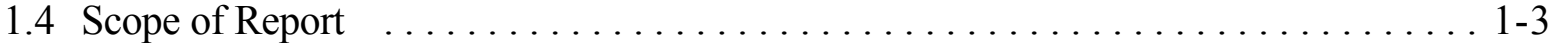

1.5 Description and Location of Shallow Soil Trenches $\ldots \ldots \ldots \ldots \ldots \ldots \ldots \ldots \ldots$

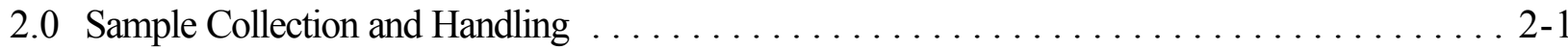

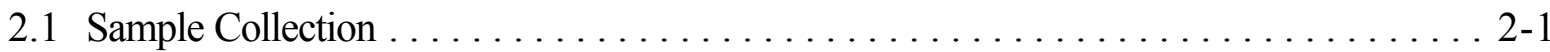

2.1 .1 Grab Samples . . . . . . . . . . . . . . . . . . . . .

2.1 .2 Core Samples . . . . . . . . . . . . . . . . . . . . . . . 2-1

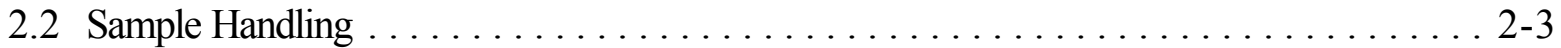

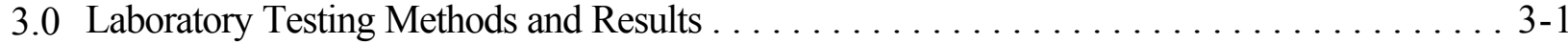

3.1 General Geologic Description $\ldots \ldots \ldots \ldots \ldots \ldots \ldots \ldots \ldots \ldots \ldots \ldots \ldots \ldots \ldots \ldots \ldots \ldots \ldots$

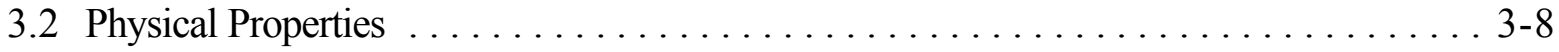

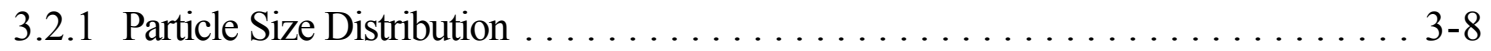

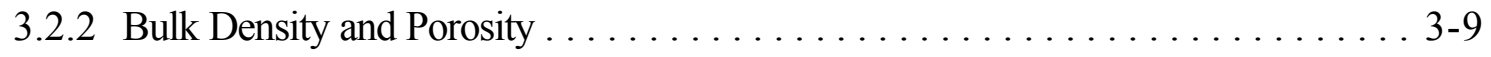

3.3 Hydrologic Properties . . . . . . . . . . . . . . . . . . . . . . . . . 3-19

3.3.1 Saturated Hydraulic Conductivity . . . . . . . . . . . . . . . . 3-19

3.4 Hydrologic Conditions . . . . . . . . . . . . . . . . . . . . . . . . . . 3-19

3.4.1 Water Content . . . . . . . . . . . . . . . . . . . . . . . 3-19

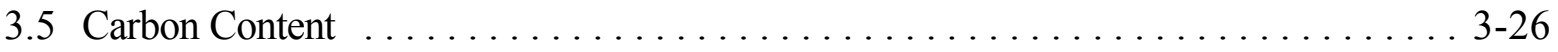

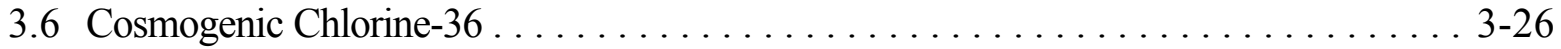

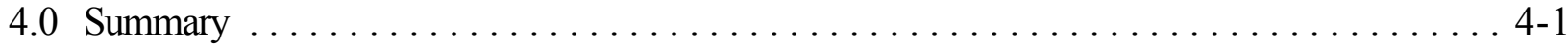

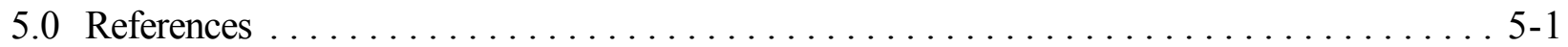

Appendix A Results of Laboratory Tests for Hydrologic and Material Properties and Carbon Content

Appendix B Results of Laboratory Tests for Gravimetric Water Content and Chlorine-36 Distribution List 


\section{List of Figures}

Number

Title

Page

1-1 Location of the Area 5 Radioactive Waste Management Site . . . . . . . . . . . . 1-2

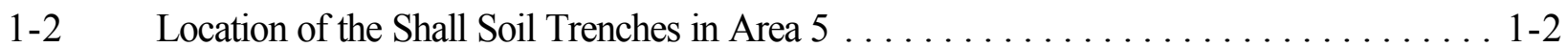

3-1 Depth Profiles of Dry-Sieve Analyses (percent passing Number 4 and

Number 200 mesh screens) for Core Samples from SST-1 . . . . . . . . . . . . . . 3-10

3-2 Depth Profiles of Dry-Sieve Analyses (percent passing Number 4 and

Number 200 mesh screens) for Core Samples from SST-2 . . . . . . . . . . . 3-11

3-3 Depth Profiles of Dry-Sieve Analyses (percent passing Number 4 and

Number 200 mesh screens) for Core Samples from SST-3 . . . . . . . . . . . . . . 3-12

3-4 Depth Profiles of Dry Bulk Density for Samples from SST-1 . . . . . . . . . . . 3 3-13

3-5 Depth Profiles of Dry Bulk Density for Samples from SST-2 . . . . . . . . . . . . 3-14

3-6 Depth Profiles of Dry Bulk Density for Samples from SST-3 . . . . . . . . . . . . 3-15

3-7 Depth Profiles of Calculated Porosity for Samples from SST-1 . . . . . . . . . 3-16

3-8 Depth Profiles of Calculated Porosity for Samples from SST-2 . . . . . . . . . . 3-17

3-9 Depth Profiles of Calculated Porosity for Samples from SST-3 . . . . . . . . . . 3-18

3-10 Depth Profiles of Saturated Hydraulic Conductivity for Samples from SST-1 . . . . . 3-20

3-11 Depth Profiles of Saturated Hydraulic Conductivity for Samples from SST-2 . . . . . 3-21

3-12 Depth Profiles of Saturated Hydraulic Conductivity for Samples from SST-3 . . . . . 3-22

3-13 Depth Profiles of Gravimetric Water Content for Grab and Core Samples

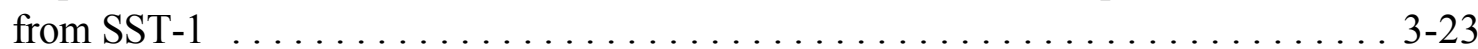

3-14 Depth Profiles of Gravimetric Water Content for Grab and Core Samples

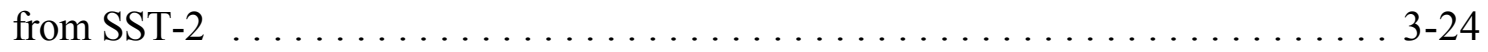

3-15 Depth Profiles of Gravimetric Water Content for Grab and Core Samples

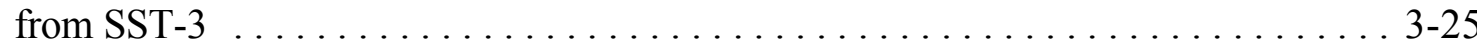

3-16 Depth Profiles of Inorganic Carbon for Core Samples from SST-1 . . . . . . . . . . . 3-27

3-17 Depth Profiles of Inorganic Carbon for Core Samples from SST-2 . . . . . . . . . . . 3-28

3-18 Depth Profiles of Inorganic Carbon for Core Samples from SST-3 . . . . . . . . . . . . 3-29

3-19 Depth Profile of ${ }^{36} \mathrm{Cl} / \mathrm{Cl}$ Ratios for Grab Samples from SST-1 at Location $0+50$ 


\section{List of Tables}

Number

1-1 Location Information for the Shallow Soil Trenches in Area $5 \ldots \ldots \ldots \ldots \ldots \ldots$

2-1 Standard Operating Procedures and Test Plans Applicable to the

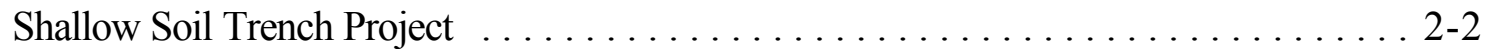

2-2 Summary of Sample Collection in the Shallow Soil Trenches $\ldots \ldots \ldots \ldots \ldots . . \ldots 2-2$

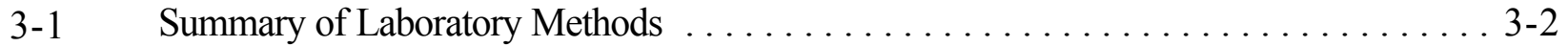

3-2 Summary of Laboratory Tests Conducted on Shallow Soils Trench Core and Grab Samples . . . . . . . . . . . . . . . . . . . . . 3-3

3-3 Summary of Descriptive Statistics for Alluvial Samples from the Shallow Soil Trenches . . . . . . . . . . . . . . . . . . . . . . . . . . 3-4

3-4 Summary of USCS Assignments for Shallow Soil Trench Core Samples and Area 5 Pilot Wells . . . . . . . . . . . . . . . . . . . . . . . 3-8

A-1 Results of Laboratory Tests for Hydrologic and Material Properties for

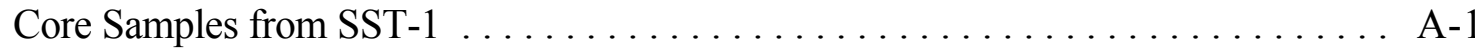

A-2 Results of Laboratory Tests for Hydrologic and Material Properties for Core Samples from SST $-2 \ldots \ldots \ldots \ldots \ldots \ldots \ldots \ldots$. . . . . . . . . . . . . . .

A-3 Results of Laboratory Tests for Hydrologic and Material Properties for

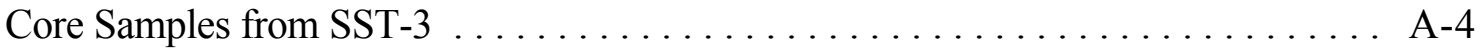

A-4 Results of Laboratory Tests for Carbon Content in Dry Soil for Core Samples

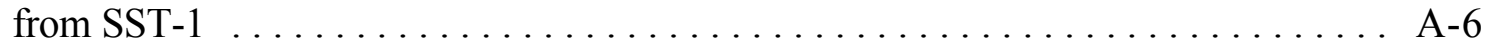

A-5 Results of Laboratory Tests for Carbon Content in Dry Soil for Core Samples

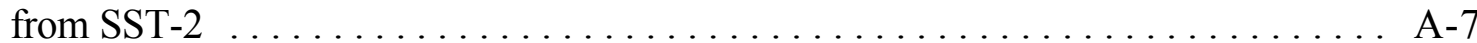

A-6 Results of Laboratory Tests for Carbon Content in Dry Soil for Core Samples

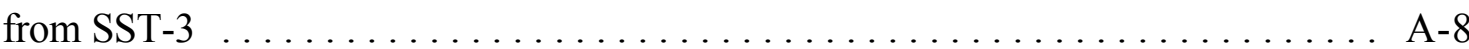

B-1 Results of Laboratory Tests for Gravimetric Water Content for Grab Samples

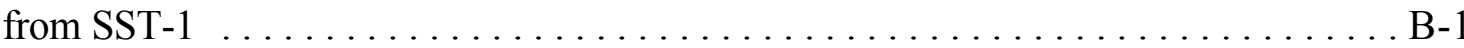

B-2 Results of Laboratory Tests for Gravimetric Water Content for Grab Samples

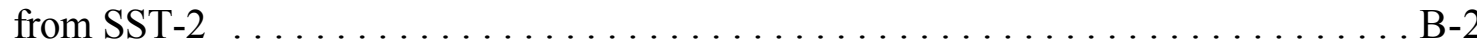

B-3 Results of Laboratory Tests for Gravimetric Water Content for Grab Samples

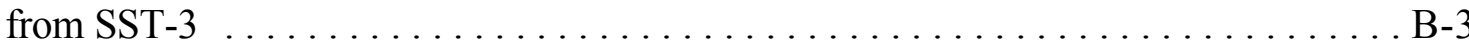

B-4 Results of Laboratory Tests for Gravimetric Water Content for Grab Samples

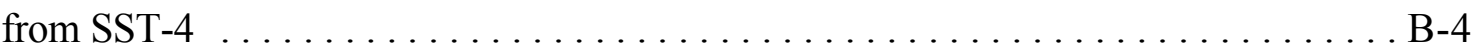

B-5 Results of Laboratory Tests for Chlorine-36 for Grab Samples from SST-1 . . . . . . . B-5 


\section{List of Acronyms and Abbreviations}

$\begin{array}{ll}\text { BN } & \text { Bechtel Nevada } \\ { }^{36} \mathrm{Cl} & \text { chlorine-36 } \\ \mathrm{ft} & \text { foot (feet) } \\ \text { in. } & \text { inch(es) } \\ \mathrm{m} & \text { meter(s) } \\ \mathrm{mm} & \text { millimeter(s) } \\ \text { NNSA/NSO } & \text { U.S. Department of Energy, National Nuclear Security Administration Nevada Site } \\ & \text { Office } \\ \text { NTS } & \text { Nevada Test Site } \\ \text { O.D. } & \text { outer diameter } \\ \text { RCRA } & \text { Resource Conservation and Recovery Act } \\ \text { REECo } & \text { Reynolds Electrical \& Engineering Co., Inc. } \\ \text { RSN } & \text { Raytheon Services Nevada } \\ \text { RWMS } & \text { Radioactive Waste Management Site } \\ \text { SNL } & \text { Sandia National Laboratories } \\ \text { SST } & \text { Shallow Soil Trench } \\ \text { USCS } & \text { Unified Soil Classification System }\end{array}$




\subsection{Introduction}

\subsection{Background Information}

The Special Projects Section of Reynolds Electrical and Engineering Co., Inc. (REECo) was responsible for characterizing the subsurface hydrogeology of the Area 5 Radioactive Waste Management Site (RWMS) (Figure 1-1) at the Nevada Test Site (NTS) for the U.S. Department of Energy, National Nuclear Security Administration Nevada Site Office (NNSA/NSO; formerly U.S. Department of Energy, Nevada Operations Office) Waste Management Division. REECo was a predecessor to Bechtel Nevada $(\mathrm{BN})$ at the NTS. This report was originally prepared under the same title by D. O. Blout and K. A. Zukosky (REECo) and K. D. Donnelson (Raytheon Services Nevada [RSN]) in September 1994, and assigned the document number, DOE/NV/11432--169. The original report has been updated to conform to current editorial standards of $\mathrm{BN}$ and of the NNSA/NSO; to correct some errors in the original unreviewed report; and to facilitate public distribution of the data contained herein.

\subsection{Project Description}

The Shallow Soil Trenches Project was the fourth in a series of Area 5 hydrogeologic site characterization projects. The previous three projects were conducted in order of increasing cost and complexity, beginning with the Existing Excavations Project (REECo, 1993a), followed by the Science Trench Boreholes Project (REECo, 1993b) and the Pilot Wells Project (REECo, 1994, updated as $\mathrm{BN}, 2005)$. These previous studies focused on collecting hydrogeologic data below the upper few meters of soil. Very little hydrogeologic data had been collected within the upper few meters of soil, so the plan to characterize the Shallow Soil Trenches was designed to fill this data gap.

\subsection{Purpose and Justification}

The primary purpose of the hydrologic characterization of the Shallow Soil Trenches Project was to characterize important physical and hydrologic soil parameters that affect the movement of water in the upper few meters of undisturbed soil in the vicinity of the Area 5 RWMS. This was not accomplished in the Existing Excavations study (REECo, 1993a) because the very near-surface was significantly disturbed during the construction of the pits and trenches. These near-surface hydrologic data were needed to help support petitions for a Resource Conservation and Recovery Act (RCRA) groundwater monitoring waiver and a RCRA exemption from liners and leachate collection/detection systems. Both the waiver and exemption were considered important NNSA/NSO long-term objectives for management of mixed waste at the Area 5 RWMS. 


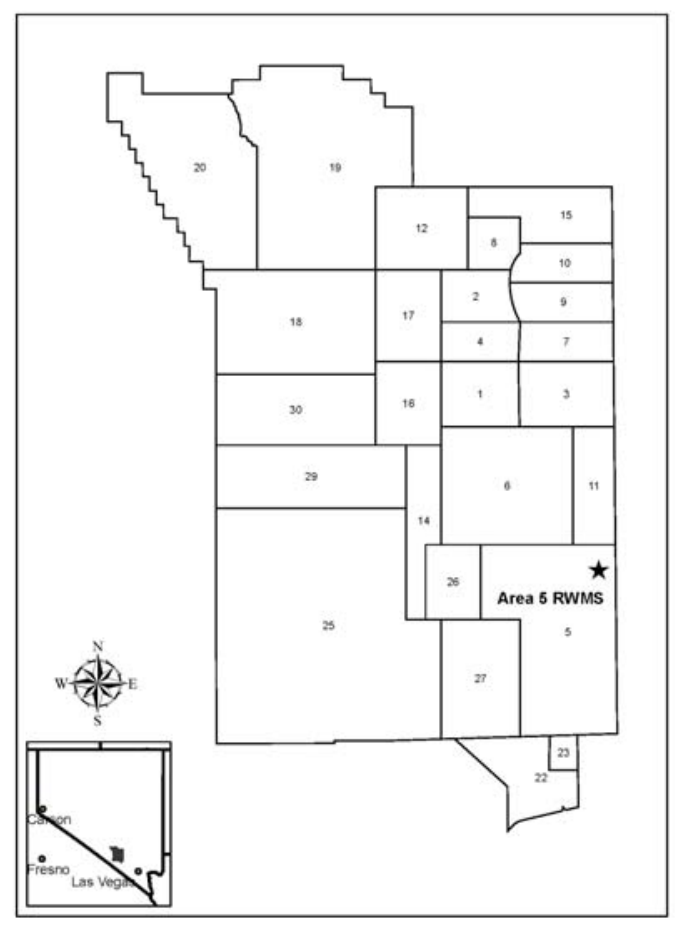

Figure 1-1

Location of the Area 5 Radioactive Waste Management Site

Figure 1-2

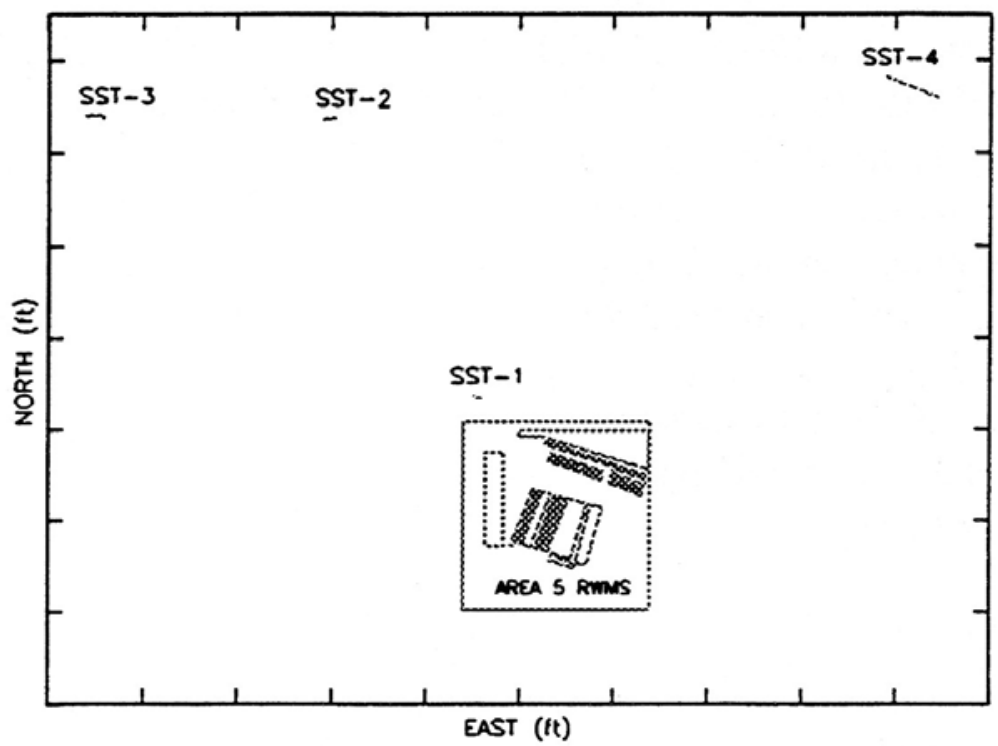

Location of the Shall Soil Trenches in Area 5

Note: Tic spacing is 304.8 meters ( 1,000 feet) 
Data from these and other studies (REECo, 1993a, 1993b, BN, 2005]) have been used in several interpretive reports (Ginanni et al., 1993; O’Neill et al., 1993; Istok et al., 1994; Johnejack et al., 1994) to show that under the present arid climate, precipitation that infiltrates into the soil is recycled back into the atmosphere by evapotranspiration processes. That is, there is no net infiltration or recharge under present climatic conditions. These findings have been used to help develop formal demonstrations that there is no potential for contaminants to migrate to the water table. Since most of the recycling of water is expected to occur in the upper few meters of soil, hydrogeologic data are required to improve the understanding of this process and thereby strengthen the demonstration of "no migration" to the water table.

\subsection{Scope of Report}

This report describes the field collection of geologic samples and the results of laboratory analyses designed to characterize important infiltration-related parameters along vertical transects in four trenches located in undisturbed sites in the vicinity of the Area 5 RWMS.

\subsection{Description and Location of Shallow Soil Trenches}

Four shallow soil trenches (Shallow Soil Trench [SST] 1 through SST-4) were excavated in 1993 and 1994 by backhoe and/or trackhoe in different alluvial fan deposits (Snyder et al., 1994) on the northern side of the Area 5 RWMS (Figure 1-2). The excavations were conducted by REECo under the direction of RSN (also a predecessor to $\mathrm{BN}$ ). RSN designed and located these shallow trenches to acquire near-surface geologic data from which to derive stratigraphic relationships, sedimentology, and Quaternary history at the RWMS. Snyder et al. (1994) described and correlated major paleosol units and geomorphic surfaces to determine the ages of the fan deposits, and evaluated the alluvium's stability with respect to erosion.

The trenches were generally oriented perpendicular (east-west) to the depositional trend of different fan deposits. At the east end of SST-3, the trench was excavated to the south. The depths of these trenches ranged from 1.5 to 3.0 meters $(\mathrm{m})$ (5 to $10 \mathrm{feet}[\mathrm{ft}]$ ) and the total horizontal trench lengths ranged from approximately 23 to $182 \mathrm{~m}$ (75 to $600 \mathrm{ft}$ ). Location information for the Shallow Soil Trenches in Area 5 is presented in Table 1-1. 
Table 1-1

Location Information for the Shallow Soil Trenches in Area 5

\begin{tabular}{|c|c|c|c|c|c|c|c|}
\hline \multirow{3}{*}{$\begin{array}{c}\text { Shallow } \\
\text { Soil } \\
\text { Trench }\end{array}$} & \multirow{3}{*}{ Elevation $^{a}$} & \multicolumn{4}{|c|}{ Nevada State Central Zone Coordinates ${ }^{b}$} & \multirow{3}{*}{$\begin{array}{l}\text { Length } \\
\text { of } \\
\text { Trench } \\
\mathrm{m}(\mathrm{ft})\end{array}$} & \multirow{3}{*}{$\begin{array}{c}\text { Depth } \\
\text { of } \\
\text { Trench } \\
\text { m (ft) }\end{array}$} \\
\hline & & \multicolumn{2}{|c|}{ West End } & \multicolumn{2}{|c|}{ East End } & & \\
\hline & & $\begin{array}{c}\text { North } \\
m^{c}(f t)\end{array}$ & $\begin{array}{l}\text { East } \\
\mathrm{m}(\mathrm{ft})\end{array}$ & $\begin{array}{l}\text { North } \\
\mathrm{m}(\mathrm{ft})\end{array}$ & $\begin{array}{l}\text { East } \\
\mathrm{m}(\mathrm{ft})\end{array}$ & & \\
\hline SST-1 & $\begin{array}{c}975 \\
(3,200)\end{array}$ & $\begin{array}{c}234,205.2 \\
(768,380.4)\end{array}$ & $\begin{array}{c}215,652.7 \\
(707,513.5)\end{array}$ & $\begin{array}{c}234,190.0 \\
(768,330.5)\end{array}$ & $\begin{array}{c}215,666.5 \\
(707,558.5)\end{array}$ & $\begin{array}{c}20.5 \\
(67.2)\end{array}$ & $\begin{array}{l}1.5 \\
(5)\end{array}$ \\
\hline SST-2 & $\begin{array}{c}1,001 \\
(3,283)\end{array}$ & $\begin{array}{c}235,110.9 \\
(771,351.7)\end{array}$ & $\begin{array}{c}215,158.6 \\
(705,892.3)\end{array}$ & $\begin{array}{c}235,119.0 \\
(771,378.4)\end{array}$ & $\begin{array}{c}215,209.3 \\
(706,058.7)\end{array}$ & $\begin{array}{c}51.4 \\
(168.5)\end{array}$ & $\begin{array}{l}3.0 \\
(10)\end{array}$ \\
\hline SST-3 & $\begin{array}{c}1,007 \\
(3,303)\end{array}$ & $\begin{array}{c}235,122.5 \\
(771,389.8)\end{array}$ & $\begin{array}{c}214,394.8 \\
(703,386.5)\end{array}$ & $\begin{array}{c}235,126.7 \\
(771,403.7)\end{array}$ & $\begin{array}{c}214,449.1 \\
(703,564.6)\end{array}$ & $\begin{array}{c}54.5 \\
(178.6)\end{array}$ & \multirow{2}{*}{$\begin{array}{l}3.0 \\
(10)\end{array}$} \\
\hline \multicolumn{2}{|c|}{ South end of SST-3 } & $\begin{array}{c}235,113.9 \\
(771,361.6)\end{array}$ & $\begin{array}{c}214,449.9 \\
(703,567.2)\end{array}$ & $\begin{array}{c}\text { Not } \\
\text { applicable }\end{array}$ & $\begin{array}{c}\text { Not } \\
\text { applicable }\end{array}$ & $\begin{array}{c}12.9 \\
(42.2)\end{array}$ & \\
\hline SST-4 & $\begin{array}{c}1,003 \\
(3,292)\end{array}$ & $\begin{array}{c}235,254.3 \\
(771,822.4)\end{array}$ & $\begin{array}{c}235,272.7 \\
(771,882.7\end{array}$ & $\begin{array}{c}235,186.5 \\
(771,599.9)\end{array}$ & $\begin{array}{c}217,156.3 \\
(712,446.3)\end{array}$ & $\begin{array}{c}184.7 \\
(605.9)\end{array}$ & $\begin{array}{c}3.0 \\
(10) \\
\end{array}$ \\
\hline
\end{tabular}

a 1929 National Geodetic Vertical Datum.

b 1927 North American Datum (NAD).

c meters

d feet 


\subsection{Sample Collection and Handling}

This section describes the collection, handling, and disposition of soil (alluvial deposits) samples from the trenches for the purpose of laboratory analysis of infiltration-related hydrogeologic parameters. Detailed procedures used to accomplish these activities were given in REECo Quality Assurance Standard Operating Procedures and Test Plans listed in Table 2-1. Core samples are defined as relatively undisturbed material, whereas grab samples were collected with pick and shovel and thus are designated as disturbed.

\subsection{Sample Collection}

Geologic samples were collected so that the bottom of one sample interval was at the top of the next interval along several vertical transects from the ground surface to the bottom of the trench. A vertical transect location is identified by the distance from a reference point in the trench; that is to say, a location of $1+50$ identifies a transect $150 \mathrm{ft}$ from the reference point. Table 2-2 summarizes the sample collection in the Shallow Soil Trenches. All vertical sampling transects were located on the north-facing (northeast and northwest in some cases) wall of each trench to minimize the rapid drying that results from direct exposure to the sunlight. Both grab and core samples were collected at most depth intervals, except where prevented by cobbles or highly cemented zones.

\subsubsection{Grab Samples}

Grab samples were collected in tins for water content measurements from each $0.15-\mathrm{m}(0.5-\mathrm{ft})$ depth interval along vertical transects immediately after the trench was excavated. An attempt was made to obtain a representative sample (approximately 600 to 800 grams [1.3 to 1.8 pounds) over the entire length of each $0.15-\mathrm{m}(0.5-\mathrm{ft})$ depth interval.

Personnel of Sandia National Laboratories (SNL) collected grab samples for cosmogenic chlorine-36 $\left({ }^{36} \mathrm{Cl}\right)$ analysis from SST-1 along transect $0+50$ at $0.15-\mathrm{m}(0.5-\mathrm{ft})$ depth intervals by filling a 500-milliliter (16.9-ounce) Nalgene ${ }^{\circledR}$ bottle with soil from the trench wall.

\subsubsection{Core Samples}

After each trench was excavated, core samples were collected from 3 vertical transects from each trench. Samples were collected using a split-spoon sampler that was 76 millimeters $(\mathrm{mm})$ (3 inches [in.]) in outer diameter (O.D.) by $0.5 \mathrm{~m}(1.7 \mathrm{ft})$ long. The sampler was driven into the 
Table 2-1

Standard Operating Procedures and Test Plans Applicable to the Shallow Soil Trench Project

\begin{tabular}{||c|l|c|c||}
\hline $\begin{array}{c}\text { Test Plans and } \\
\text { Procedures }\end{array}$ & \multicolumn{1}{|c||}{ Title } & Date & Revision \\
\hline \hline $\begin{array}{c}\text { ER\&TDD- } \\
\text { SP.01.01 }\end{array}$ & Handling and Transport of Characterization Samples & $02 / 16 / 1994$ & 1 \\
\hline $\begin{array}{c}\text { ER\&TDD- } \\
\text { SP.01.11 }\end{array}$ & Handling In-Progress Data Records & $02 / 16 / 1994$ & 1 \\
\hline WMD-T15 & $\begin{array}{l}\text { Testing and Sampling Existing Waste Disposal } \\
\text { Excavations }\end{array}$ & $02 / 20 / 1992$ & 0 \\
\hline $\begin{array}{l}\text { ER\&TDD- } \\
\text { SP.01.05 }\end{array}$ & Gravimetric Moisture Content Determination & $02 / 16 / 1994$ & 0 \\
\hline \hline
\end{tabular}

Table 2-2

Summary of Sample Collection in the Shallow Soil Trenches

\begin{tabular}{|c|c|c|c|}
\hline Shallow Soil Trench & Location & $\begin{array}{c}\text { Number of } \\
\text { Grab Samples }\end{array}$ & $\begin{array}{c}\text { Number of } \\
\text { Core Samples }\end{array}$ \\
\hline \multirow{6}{*}{ SST-1 } & $0+10$ & 8 & 19 \\
\hline & $0+25$ & 8 & 17 \\
\hline & $0+45$ & 8 & 18 \\
\hline & $0+50$ & 6 & 0 \\
\hline & $0+60$ & 7 & 0 \\
\hline & Total & 37 & 54 \\
\hline \multirow{4}{*}{ SST-2 } & $0+13$ & 19 & 21 \\
\hline & $0+83$ & 19 & 21 \\
\hline & $1+50$ & 20 & 22 \\
\hline & Total & 58 & 64 \\
\hline \multirow{4}{*}{ SST-3 } & $0+25$ & 18 & 21 \\
\hline & $1+25$ & 18 & 23 \\
\hline & $2+00$ & 10 & 20 \\
\hline & Total & 46 & 64 \\
\hline SST- $4^{a}$ & Total & 240 & 0 \\
\hline
\end{tabular}

a Samples collected from 12 transects 15.2 meters (50 feet) apart. 
ground using a gasoline-powered jackhammer. Core samples were contained in stainless-steel liners inside the split-spoon sampler. The liners were $63 \mathrm{~mm}$ (2.5 in.) O.D. by $76 \mathrm{~mm}$ (3 in.) long.

The split-spoon sampler was advanced downward in approximately $0.5-\mathrm{m}(1.7-\mathrm{ft})$ stages from horizontal benches excavated perpendicular to the vertical trench wall (approximately $0.6 \mathrm{~m}[2.0 \mathrm{ft}]$ ) back into the undisturbed alluvium). If an obstruction (e.g., boulder) was encountered prior to sampling a $0.5-\mathrm{m}(1.7-\mathrm{ft})$ interval, the obstruction was removed and coring was continued to the bottom of the interval. After each sample was collected, the trench was excavated another $0.5 \mathrm{~m}(1.7 \mathrm{ft})$ and the sampling process was repeated.

Often several days or weeks passed between the time a portion of a trench was excavated and the time it was possible to begin core sampling. Safety and logistics problems prevented entering the trench for long periods of time while the trench was still being excavated. To ensure that the moisture contents of core samples were representative of in-situ conditions, the horizontal sampling benches were excavated approximately $0.6 \mathrm{~m}$ (2.0 ft) back into undisturbed alluvium (from the old exposed trench wall face) just prior to collecting core samples.

\subsection{Sample Handling}

Grab and core samples were handled in the field and during subsequent storage and transport in such a manner as to minimize evaporative water loss and thus ensure that the water content of the samples represented in-situ conditions. In the field, soil samples were temporarily stored in plastic ice chests placed in the shade to minimize temperature fluctuations. The ice chests were transported to a constant-temperature building several times each day.

After removing the core from the split-spoon sampler, each segment was capped, taped, and labeled with appropriate sample-identification and intended-use information. Core segments were then sealed in Protec-Core ${ }^{\circledR}$ (a tubular aluminized mylar laminate which protects the core from tampering, damage, and moisture loss when correctly sealed) and labeled again with the same information.

Grab samples collected in tins were sealed and leveled in the same manner as the core samples. Initial weights were obtained for these samples as soon as they were delivered to the constant-temperature building. 
This page intentionally left blank. 


\subsection{Laboratory Testing Methods and Results}

A summary of laboratory tests and testing methods is given in Table 3-1, and specific details are contained in the cited references. In addition, descriptions of all laboratory testing methods used in the Shallow Soil Trench Project are given in the Science Trench Borehole data report (REECo, 1993b).

Core samples were sent to Daniel B. Stephens \& Associates in Albuquerque, New Mexico, for measurement of initial water content, bulk density, porosity, saturated hydraulic conductivity, particle size distribution, and inorganic carbon. The samples SNL collected for measurement of cosmogenic ${ }^{36} \mathrm{Cl}$ were prepared by Hydro Geo Chem, Inc. in Tucson, Arizona, and the analyses were performed by Lawrence Livermore National Laboratory in Livermore, California. All measurements, with the exception of inorganic/organic carbon, were conducted on one core segment from each depth interval. A separate core segment was used for carbon analysis. In most cases these two core segments were adjacent to each other.

The types and numbers of tests conducted on core and grab samples for each trench are summarized in Table 3-2. The tabular results from these laboratory tests for both core and grab samples are listed in the Appendix. Summary statistics for laboratory measurements, where appropriate, are presented in Table 3-3. Plots of laboratory testing results for specific tests are presented in the appropriate sections which follow.

\subsection{General Geologic Description}

The alluvium exposed and sampled in the Shallow Soil Trenches is the same material found and described in other studies at the Area 5 RWMS (REECo, 1993a, 1993b, BN, 2005). The material in SST-2 and SST-3 is composed predominantly of tuffaceous material, whereas the alluvium in SST-1 and portions of SST-4 contains clasts of Paleozoic quartzite and limestone among the tuffaceous material. SST-4 also includes sections dominated by clasts of quartzite and limestone. The alluvium is generally weakly cemented to cemented and has a weak to moderate reaction to dilute hydrochloric acid. Poorly graded gravels and coarse sand fractions are more subangular than well graded fractions of similar particle size. The general color of the alluvium is very pale brown to light yellowish brown.

The Unified Soil Classification System (USCS) textural data are summarized in Table 3-4. These textural classes are composed primarily of sand with silt, some gravel, and no clay-size 
Table 3-1

Summary of Laboratory Methods

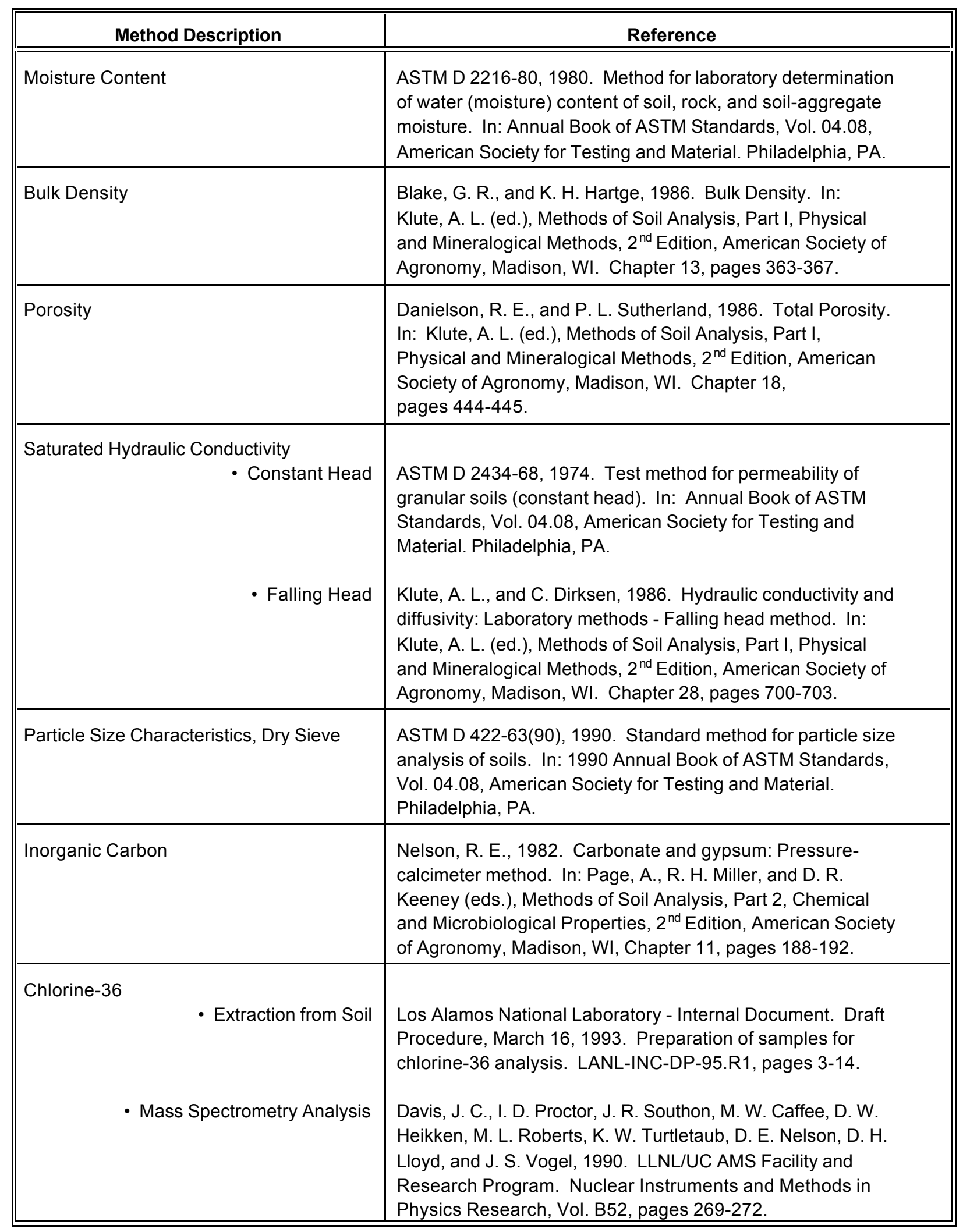


Table 3-2

Summary of Laboratory Tests Conducted on Shallow Soils Trench Core and Grab Samples

\begin{tabular}{||l|c|c|c|c|c|c|c||}
\hline \multirow{2}{*}{ Test } & \multicolumn{2}{c|}{ SST-1 } & \multicolumn{2}{c|}{ SST-2 } & \multicolumn{2}{c||}{ SST-3 } & SST-4 \\
\cline { 2 - 9 } & Grab & Core & Grab & Core & Grab & Core & Grab \\
\hline \hline Gravimetric Water Content & 31 & 26 & 58 & 35 & 46 & 37 & 240 \\
\hline Volumetric Water Content & -- & 23 & -- & 35 & -- & 37 & -- \\
\hline Saturated Hydraulic Conductivity & -- & 23 & -- & 32 & -- & 33 & -- \\
\hline Dry Bulk Density & -- & 23 & -- & 35 & -- & 33 & -- \\
\hline Calculated Porosity & -- & 23 & -- & 35 & -- & 33 & -- \\
\hline Particle Size Distribution & -- & 26 & -- & 36 & -- & 37 & -- \\
\hline Organic Matter & -- & 28 & -- & 43 & -- & 38 & -- \\
\hline Chlorine-36 & 7 & -- & -- & -- & -- & -- & -- \\
\hline \hline
\end{tabular}

Number of tests conducted. -- = Test not conducted. 


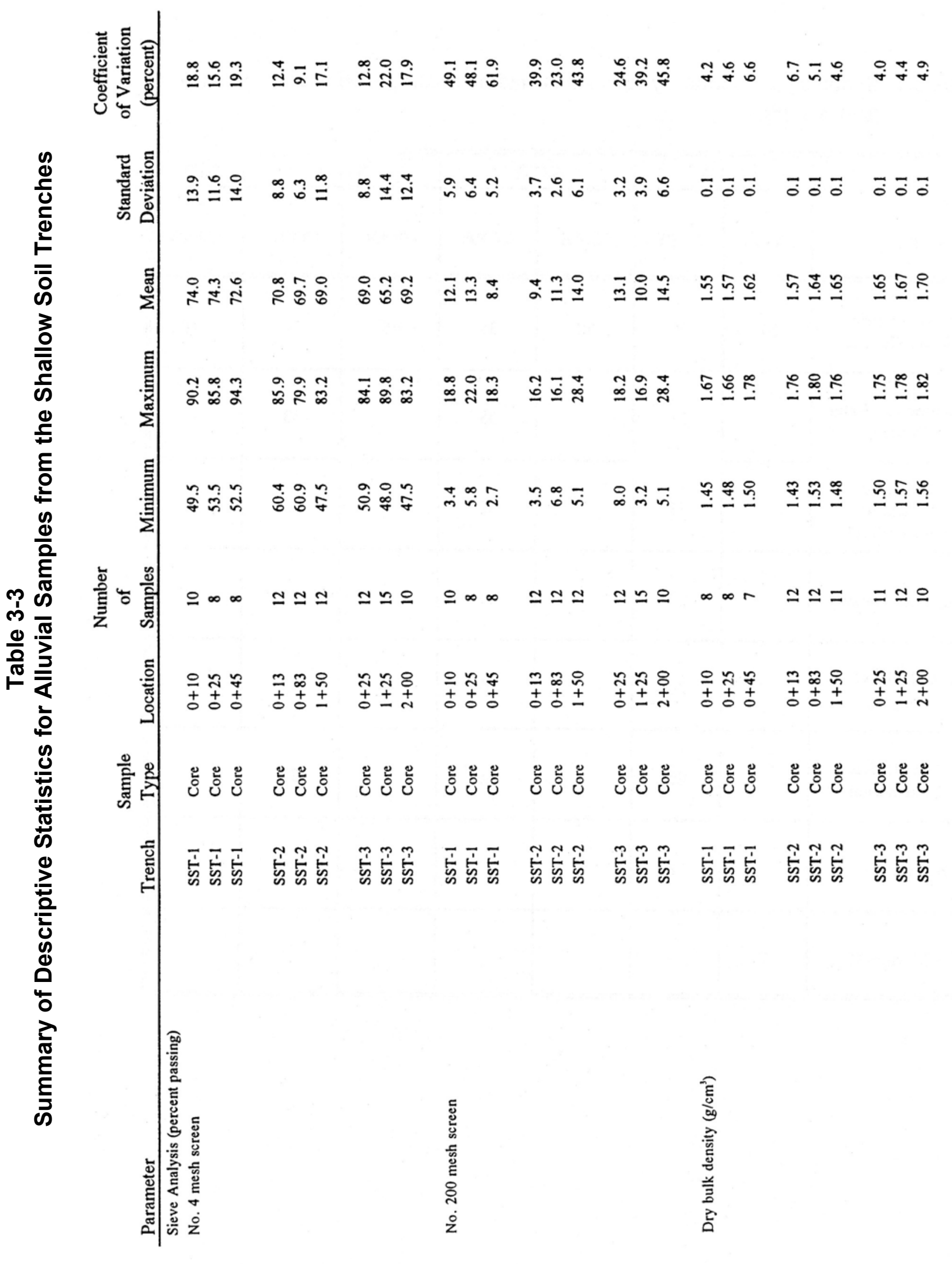




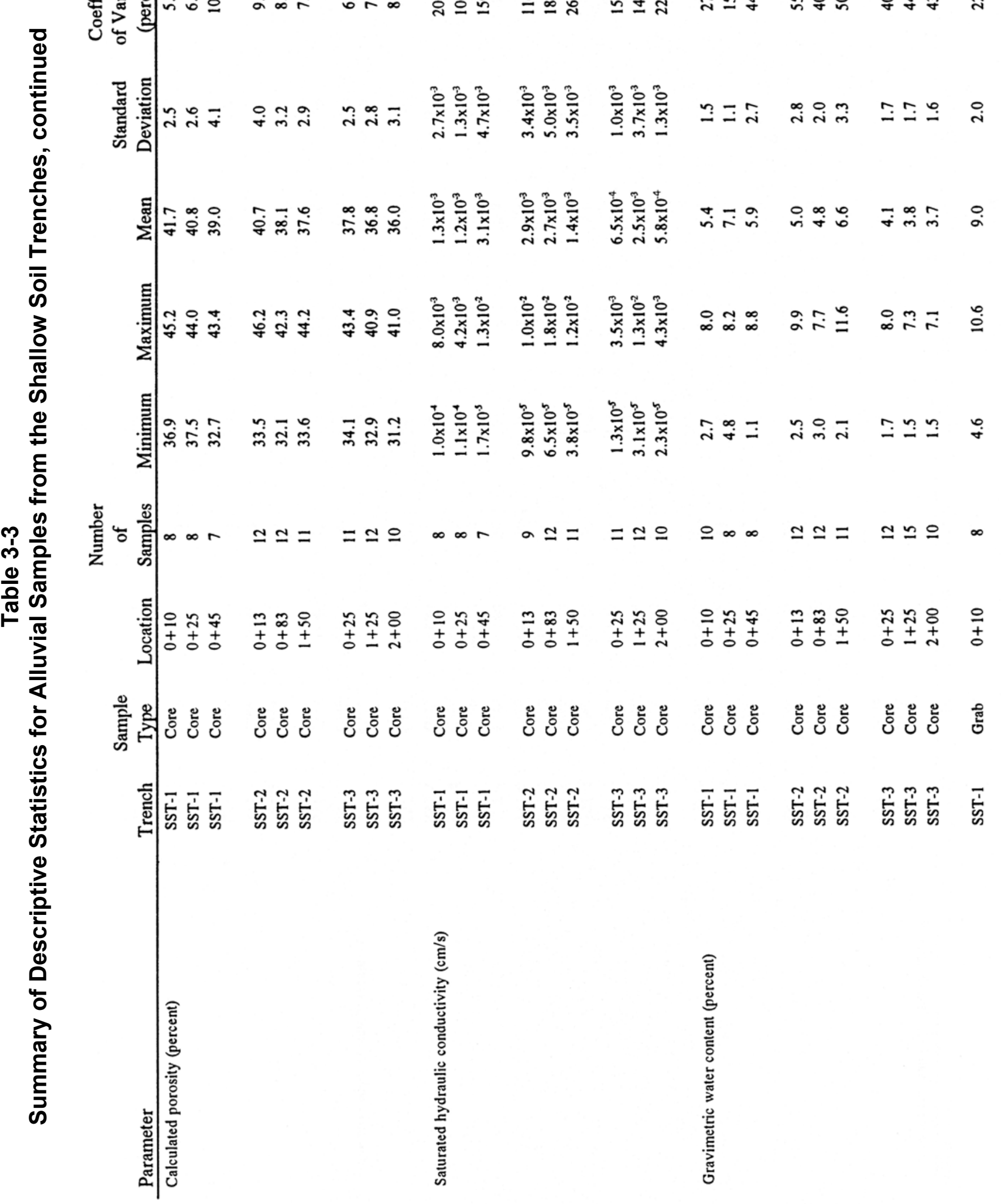

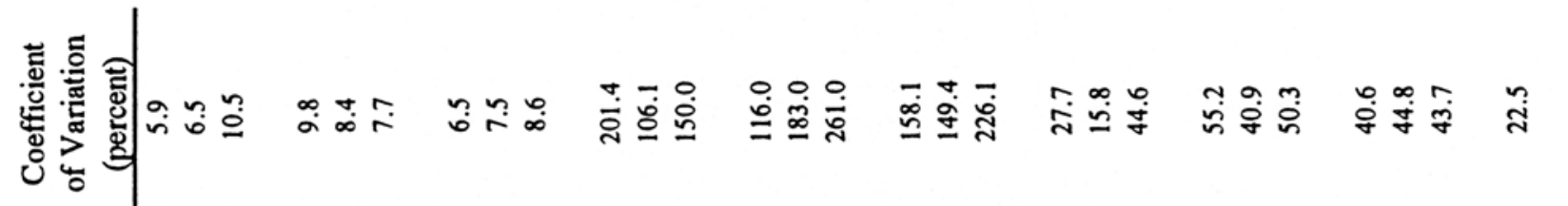




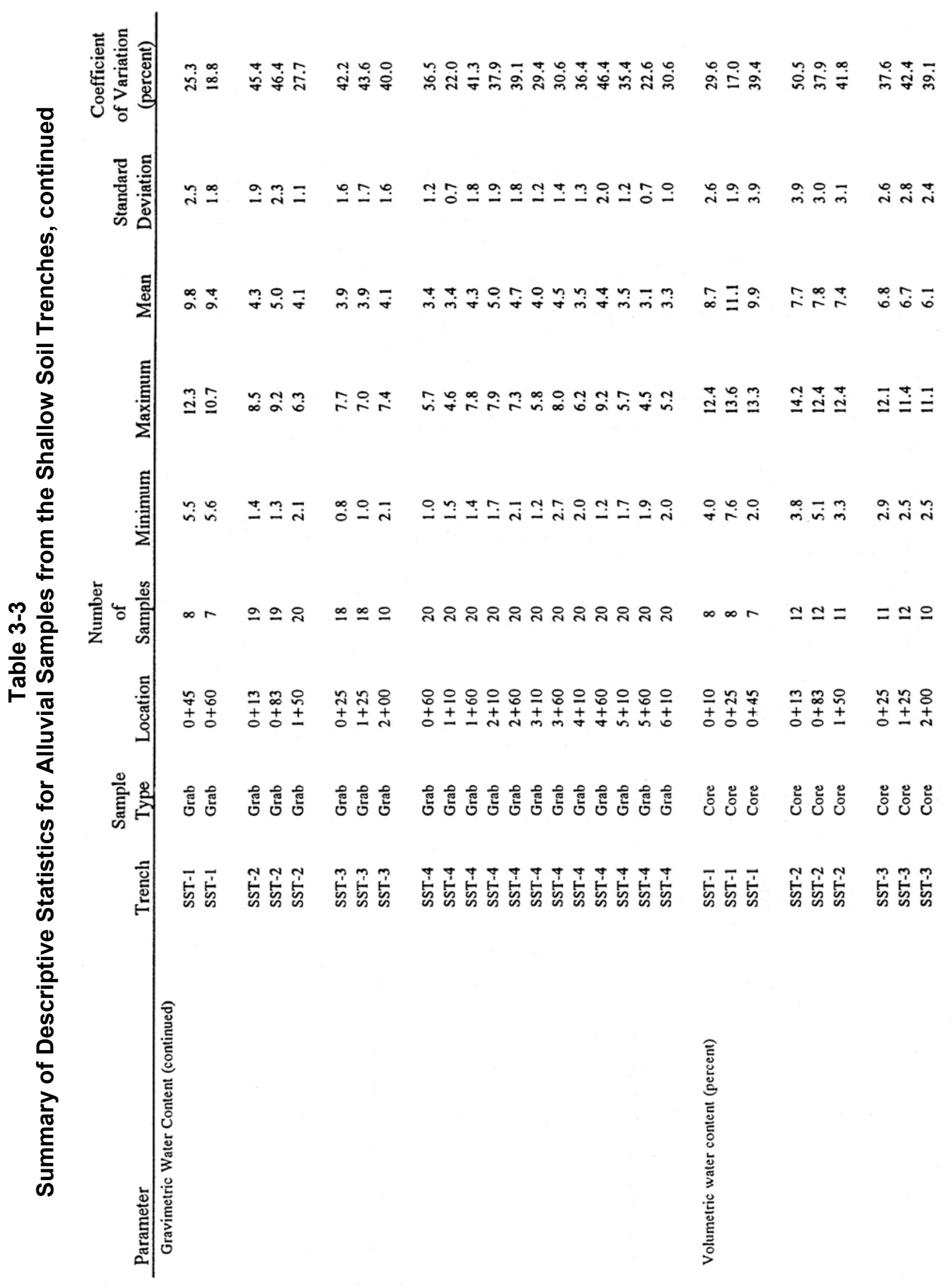




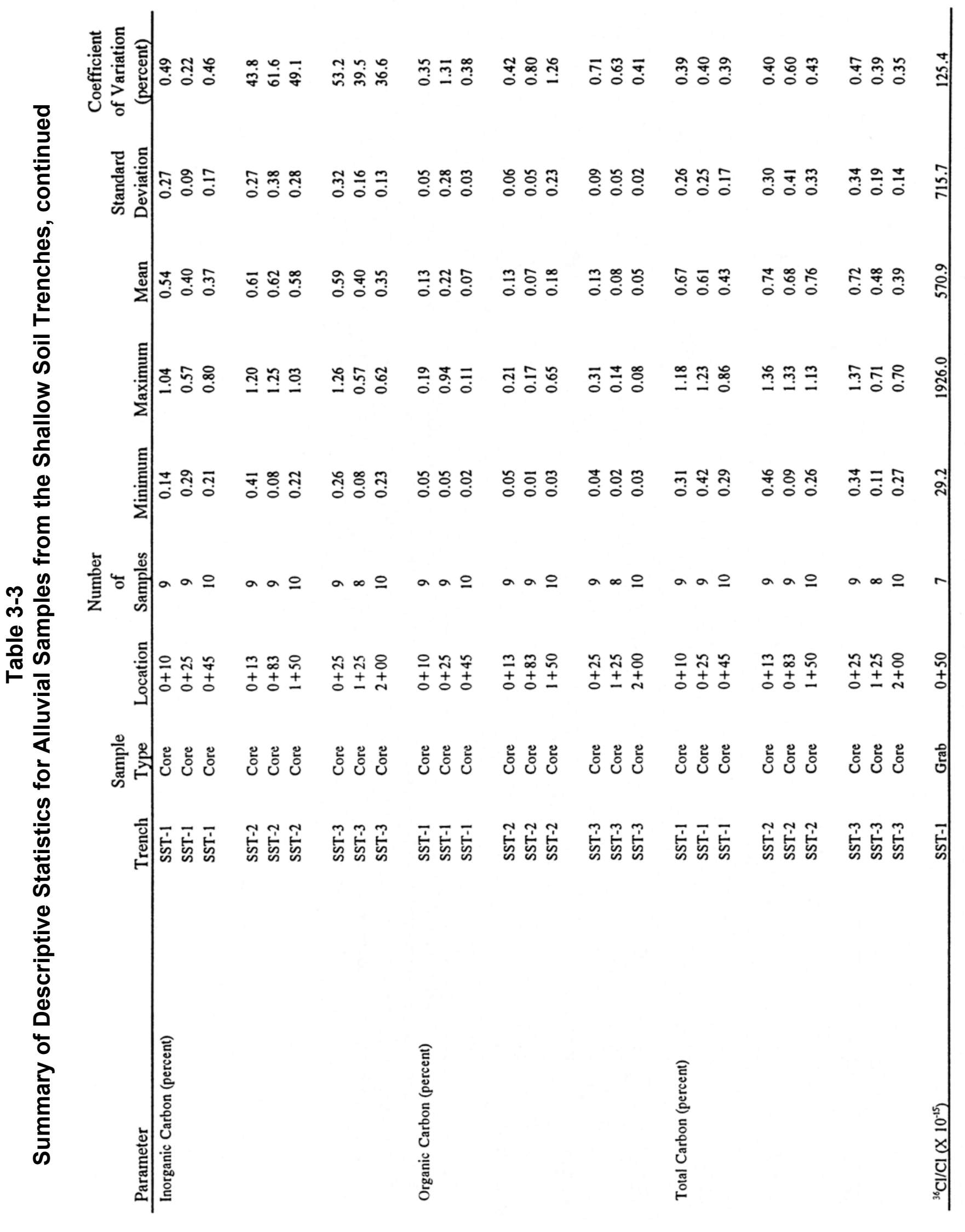


Table 3-4

Summary of USCS Assignments for Shallow Soil Trench Core Samples and Area 5 Pilot Wells

\begin{tabular}{|c|c|c|c|c|c|c|c|c|c|c|}
\hline \multirow{2}{*}{ Borehole } & \multicolumn{10}{|c|}{ Number and Percent ( ) of Samples with Given USCS Group Names ${ }^{a}$} \\
\hline & SM & SP-SM & SW-SM & SP & SW & GM & GP & GW & GW-GM & Total \\
\hline SST-1 & $\begin{array}{c}13 \\
(50.0) \\
\end{array}$ & -- & $\begin{array}{c}8 \\
(30.8) \\
\end{array}$ & -- & $\begin{array}{c}3 \\
(11.5) \\
\end{array}$ & -- & -- & -- & $\begin{array}{c}2 \\
(7.7) \\
\end{array}$ & 26 \\
\hline SST-2 & $\begin{array}{c}12 \\
(33.3) \\
\end{array}$ & -- & $\begin{array}{c}21 \\
(58.3) \\
\end{array}$ & -- & $\begin{array}{c}2 \\
(5.6) \\
\end{array}$ & $\begin{array}{c}1 \\
(2.8) \\
\end{array}$ & -- & -- & -- & 36 \\
\hline SST-3 & $\begin{array}{c}16 \\
(43.2) \\
\end{array}$ & -- & $\begin{array}{c}15 \\
(40.5) \\
\end{array}$ & -- & $\begin{array}{c}1 \\
(2.7) \\
\end{array}$ & $\begin{array}{c}1 \\
(2.7)\end{array}$ & -- & -- & $\begin{array}{c}4 \\
(10.9)\end{array}$ & 36 \\
\hline UE5 PW-1 ${ }^{b}$ & $\begin{array}{c}5 \\
(8.9)\end{array}$ & $\begin{array}{c}5 \\
(8.9)\end{array}$ & $\begin{array}{c}24 \\
(42.8)\end{array}$ & $\begin{array}{c}1 \\
(1.8)\end{array}$ & $\begin{array}{c}19 \\
(34.0)\end{array}$ & -- & -- & $\begin{array}{c}2 \\
(3.6)\end{array}$ & -- & 56 \\
\hline UE5 PW-2 ${ }^{\mathrm{b}}$ & $\begin{array}{c}10 \\
(38.5)\end{array}$ & -- & $\begin{array}{c}15 \\
(57.5)\end{array}$ & $\begin{array}{c}1 \\
(3.8)\end{array}$ & -- & -- & -- & -- & -- & 26 \\
\hline UE5PW-3 ${ }^{b}$ & $\begin{array}{c}9 \\
(36)\end{array}$ & -- & $\begin{array}{c}12 \\
(48)\end{array}$ & (16) & 4 & -- & -- & -- & -- & 25 \\
\hline
\end{tabular}
a SM: $\quad$ Silty sand (>12\%silt)
SW: $\quad$ Well graded sand ( $<5 \%$ silt $)$
SP-SM: $\quad$ Poorly graded sand with silt (5 to $12 \%$ silt) GM: $\quad$ Silty gravel (> $12 \%$ silt)
SW-SM: Well graded sand with silt ( 5 to $12 \%$ silt) $\quad$ GP: $\quad$ Poorly graded gravel ( $<5 \%$ silt)
SP: $\quad$ Poorly graded sand ( $<5 \%$ silt)
GW-GM: Well graded gravel with silt (5 to $12 \%$ silt)
-- $\quad$ No samples in this USCS group

b Data source: BN, 2005

fraction. The predominant class for SST-1 and SST-3 is silty sand (USCS class SM) and for SST-2, a well graded sand with silt (SW-SM). The samples for the near-surface are generally composed of a finer texture when compared with the Pilot Wells (BN, 2005), as would be expected. Again, this is consistent with the results from other studies in the area.

\subsection{Physical Properties}

Several physical properties that are relatively easy and inexpensive to measure, provide valuable insight into understanding the near-surface hydrogeologic system in the vicinity of the Area 5 RWMS. These physical properties include particle size distribution, bulk density, and porosity.

\subsubsection{Particle Size Distribution}

Particle size distribution analysis was conducted on the core sample using a dry sieve method (Table 3-1). Previous analyses (REECo, 1993a) indicated only small differences between the dry sieve and the more expensive wet sieve methods on these relatively coarse-grained alluvial materials. 
Because the sieve process destroys the physical integrity of the core samples, this test always followed a series of non-destructive physical and hydrologic tests on the same core sample. These precursor tests included saturated porosity, saturated hydraulic conductivity, and moisture retention measurements.

The results of particle size distribution analysis are presented in tabular form in Appendix A. Data from the Number 4 and Number 200 mesh screens (percent of material passing) for core samples collected from trenches SST-1, SST-2, and SST-3 are plotted versus depth in Figures 3-1, 3-2, and 3-3, respectively. These figures illustrate the relative percent of materials falling into the gravel, sand, and silt/clay fractions at each depth, and show that the particle size distribution of alluvial materials is remarkably similar with depth. These materials are composed predominantly of sand-sized particles with considerable amounts of gravel, and typically contain less than 10 percent silt and clay.

Descriptive statistics of Number 4 and Number 200 mesh screen data for core samples from all three trenches are summarized in Table 3-3. Statistics have been calculated separately for each transect. Mean values from both screens are similar and consistent between transects and between trenches. These data are also consistent with the results from other studies in the area (REECo, 1993a, 1993b; $\mathrm{BN}, 2005)$.

\subsubsection{Bulk Density and Porosity}

Dry bulk densities were determined on the core samples and are presented in tabular form in Appendix A. Plots of alluvial bulk densities versus depth for each trench are presented in Figures 3-4, 3-5, and 3-6. There appear to be no consistent trends in bulk density with depth. This may be due in part to the similarity of the particle size distribution (Section 3.2.1).

Porosities were calculated from dry bulk densities using a particle density of 2.65 grams per cubic centimeter (165 pounds per cubic foot). Calculated porosities are plotted versus depth in Figures 3-7, 3-8, and 3-9. Descriptive statistics of dry bulk densities and porosities of alluvium samples are summarized in Table 3-3. Mean values and coefficients of variation of dry bulk densities and calculated porosities (by definition) for each trench are nearly identical. Bulk densities near both the lower and higher ends of the range may reflect sampling disturbance rather than in situ conditions. 


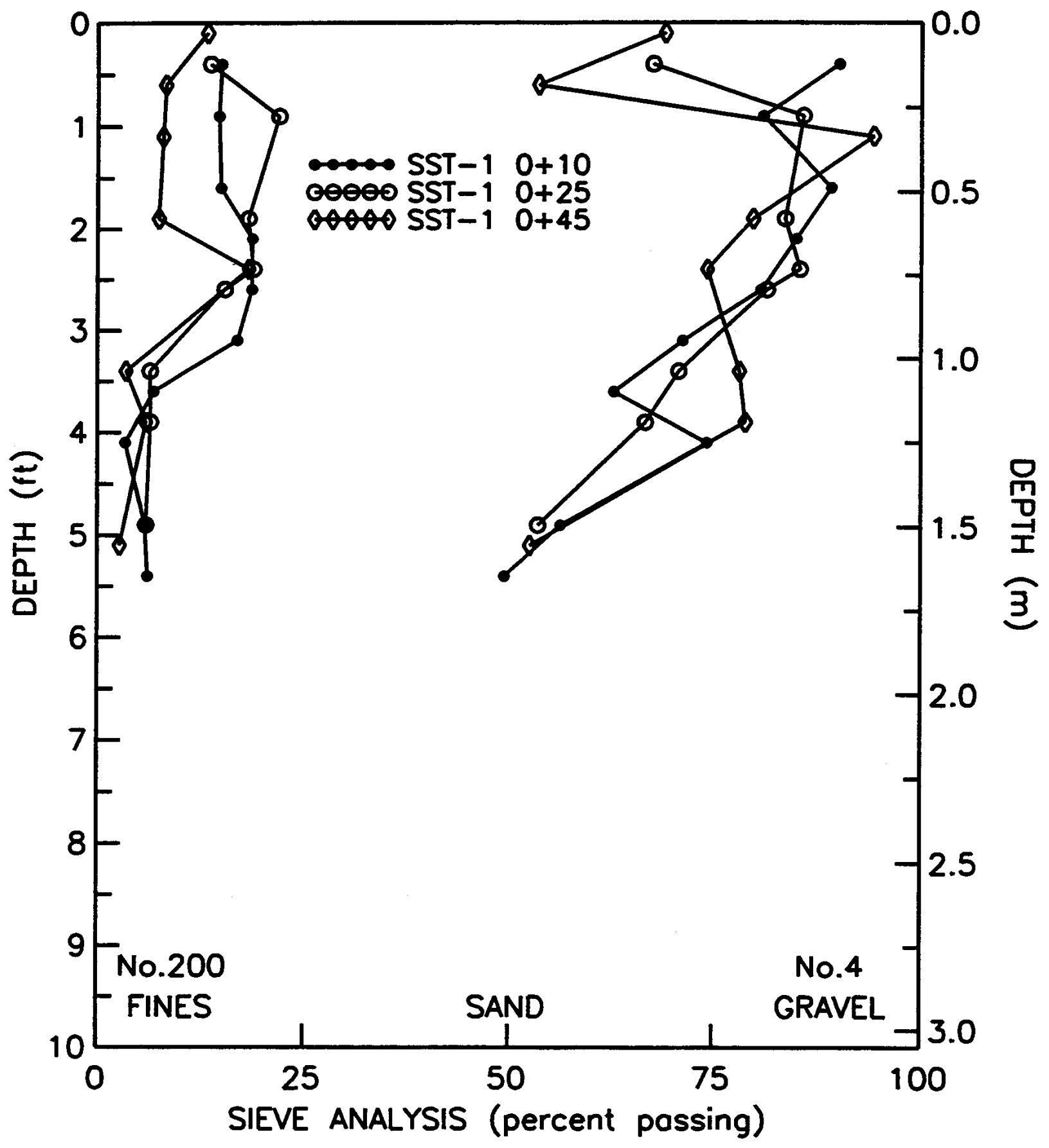

Figure 3-1

Depth Profiles of Dry-Sieve Analyses (percent passing Number 4 and Number 200 mesh screens) for Core Samples from SST-1 


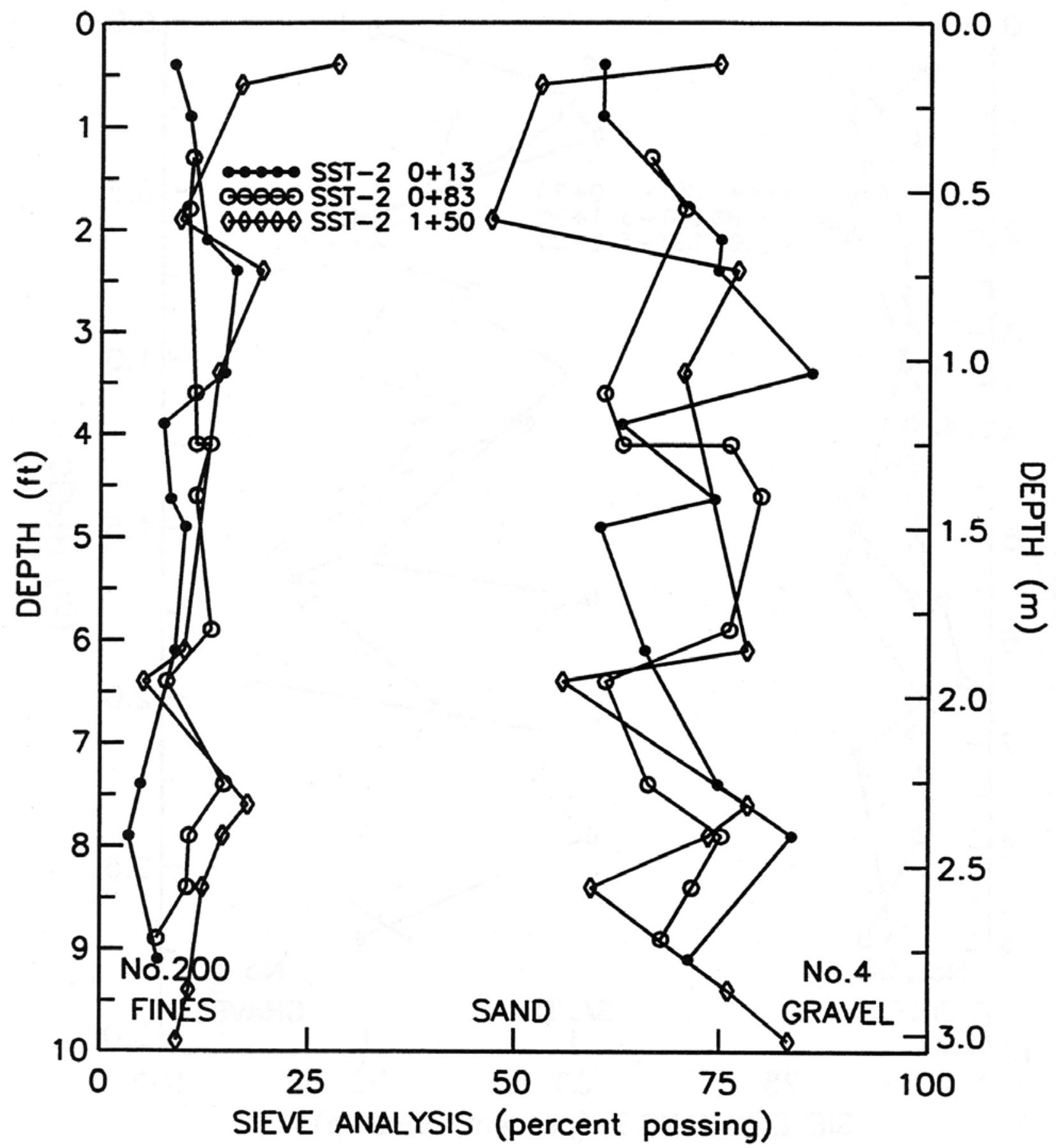

Figure 3-2

Depth Profiles of Dry-Sieve Analyses (percent passing Number 4 and Number 200 mesh screens) for Core Samples from SST-2 


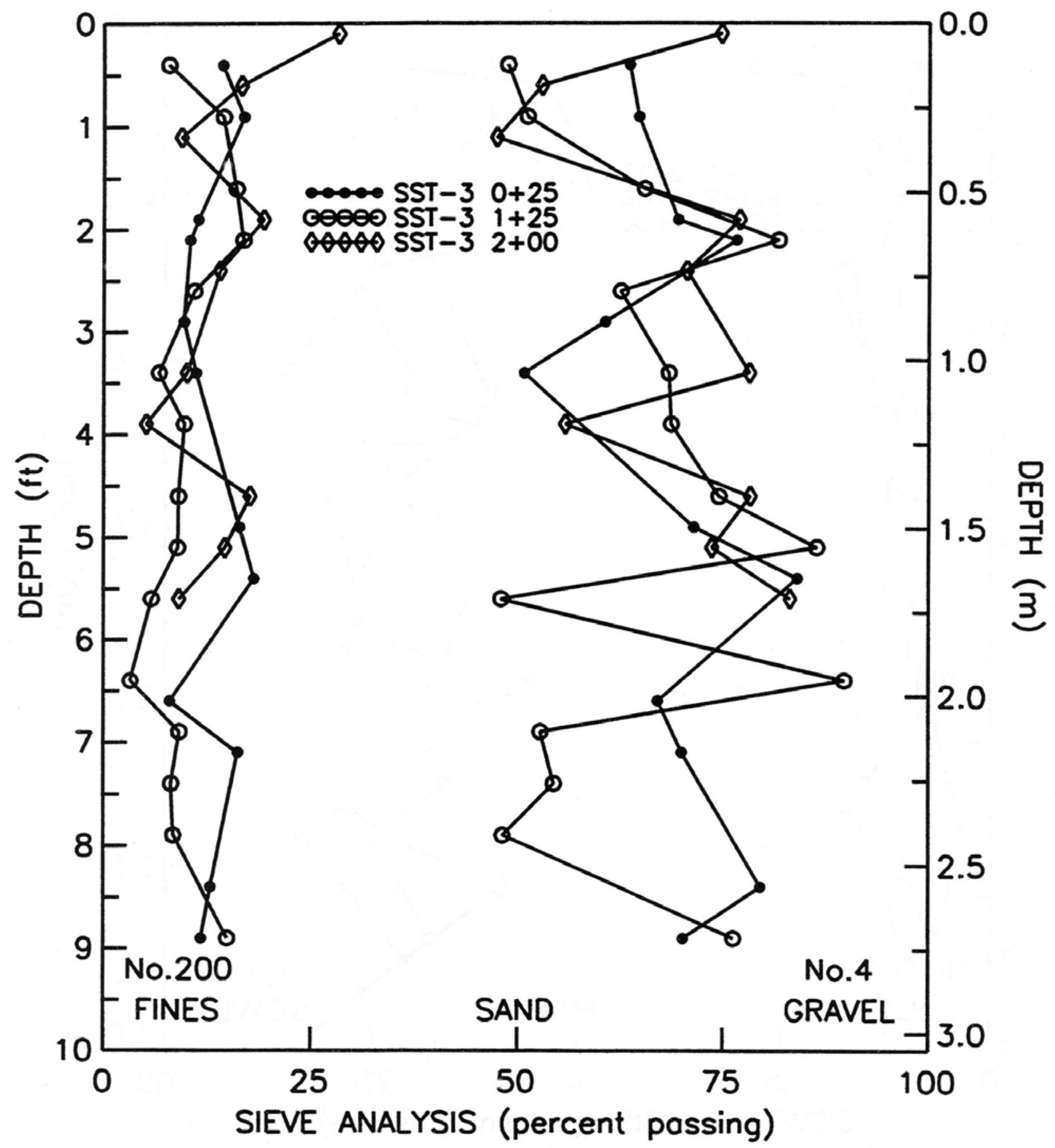

Figure 3-3

Depth Profiles of Dry-Sieve Analyses (percent passing Number 4 and Number 200 mesh screens) for Core Samples from SST-3 


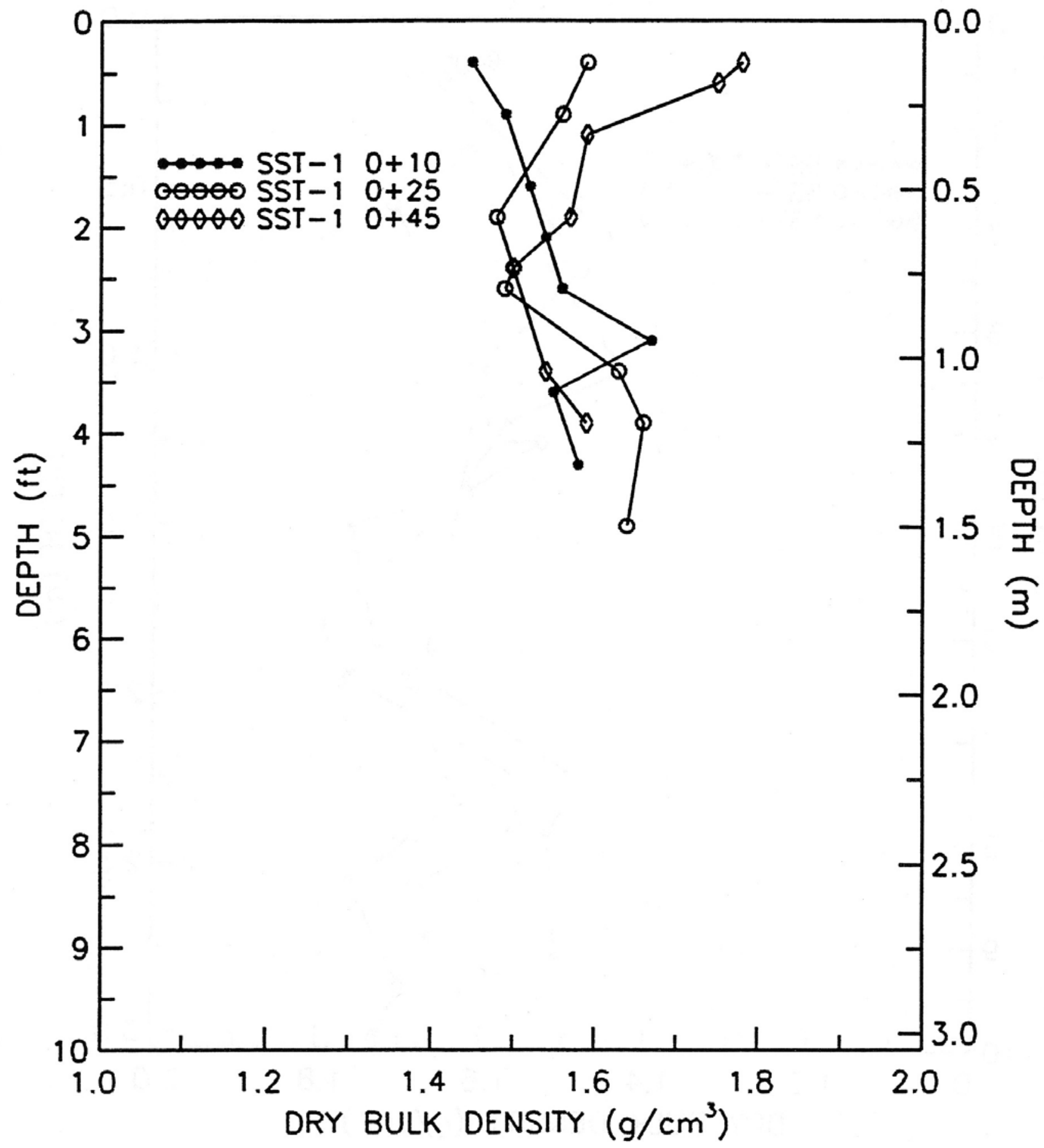

Figure 3-4

Depth Profiles of Dry Bulk Density for Samples from SST-1 


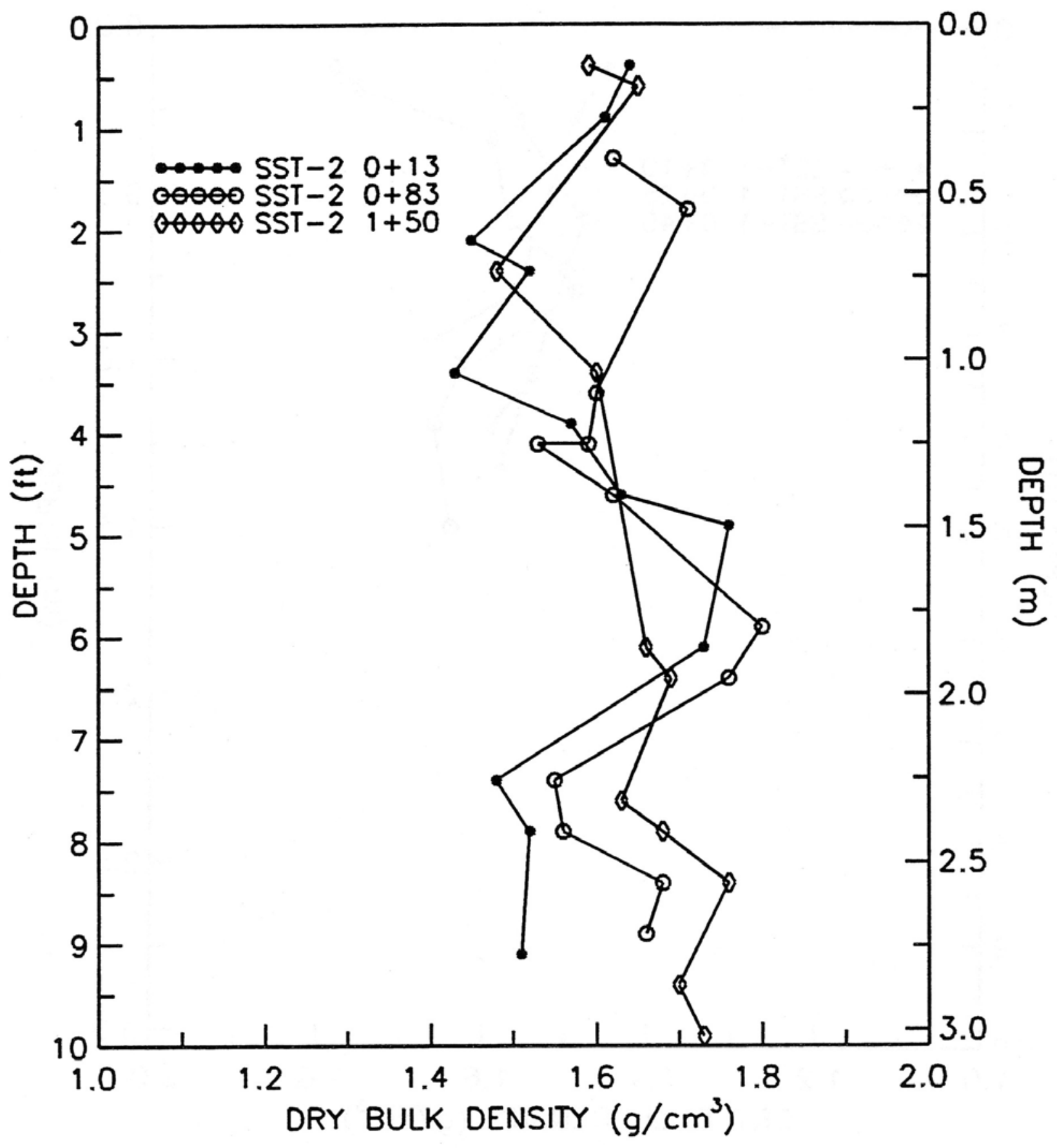

Figure 3-5

Depth Profiles of Dry Bulk Density for Samples from SST-2 


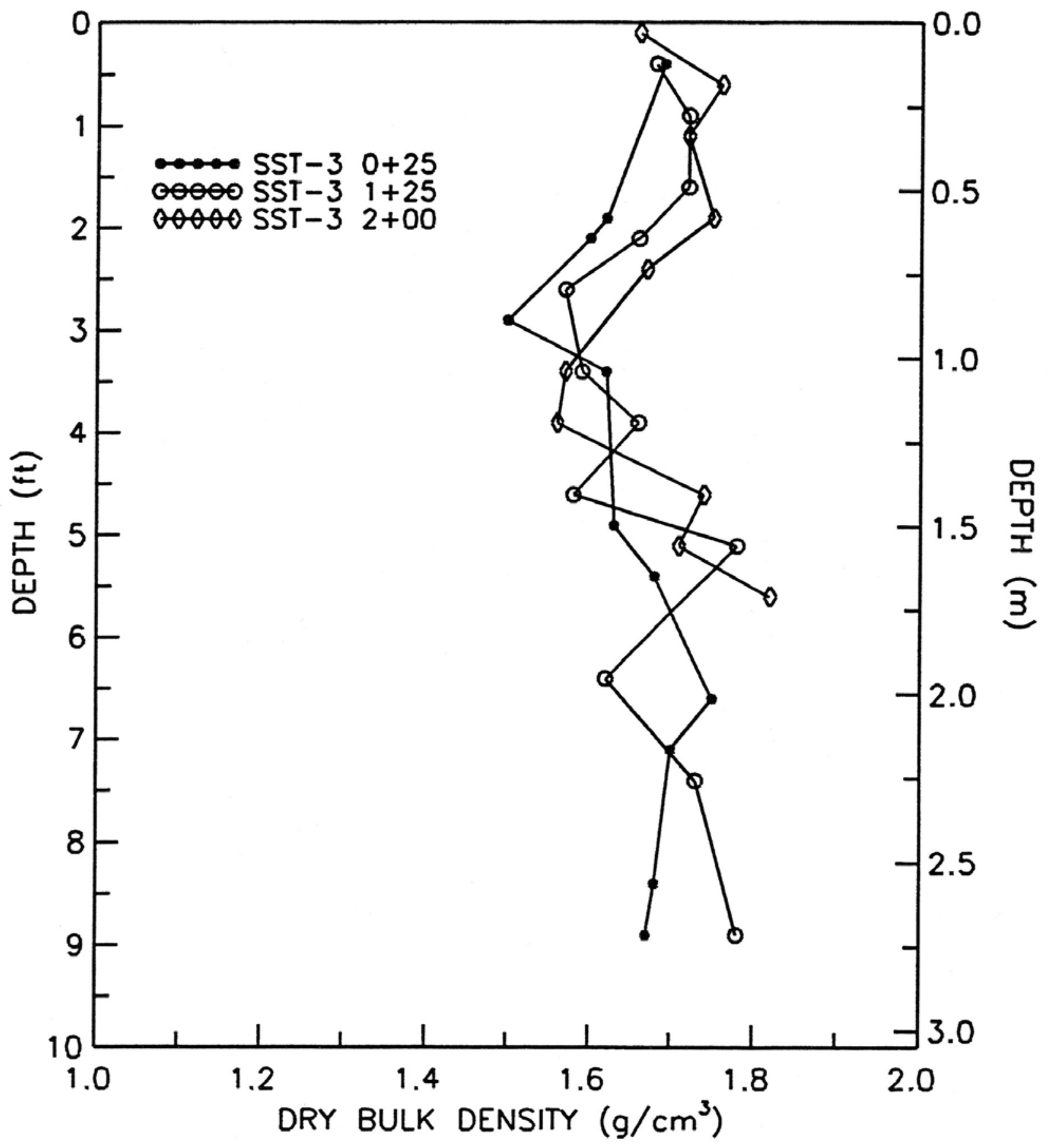

Figure 3-6

Depth Profiles of Dry Bulk Density for Samples from SST-3 


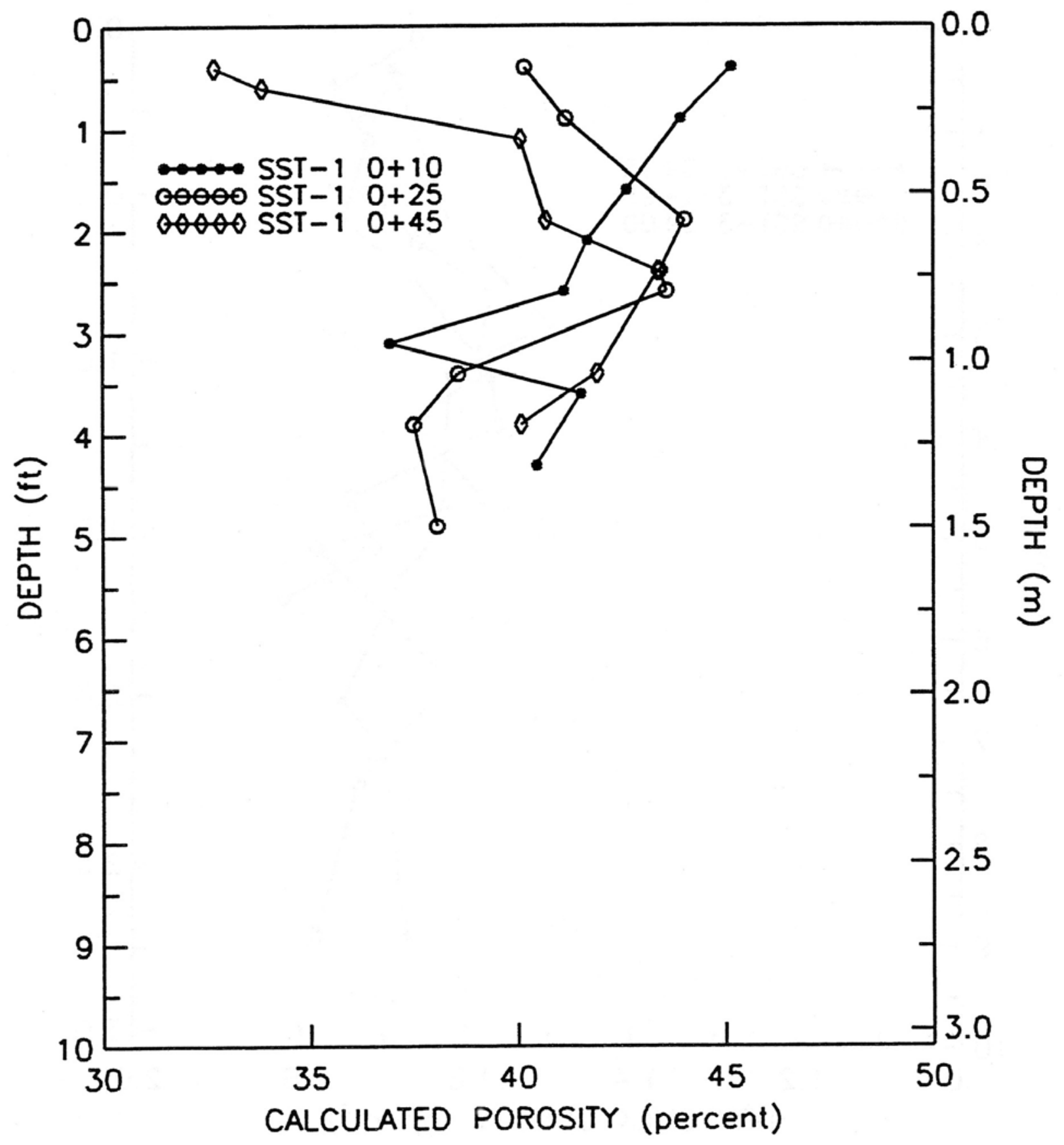

Figure 3-7

Depth Profiles of Calculated Porosity for Samples from SST-1 


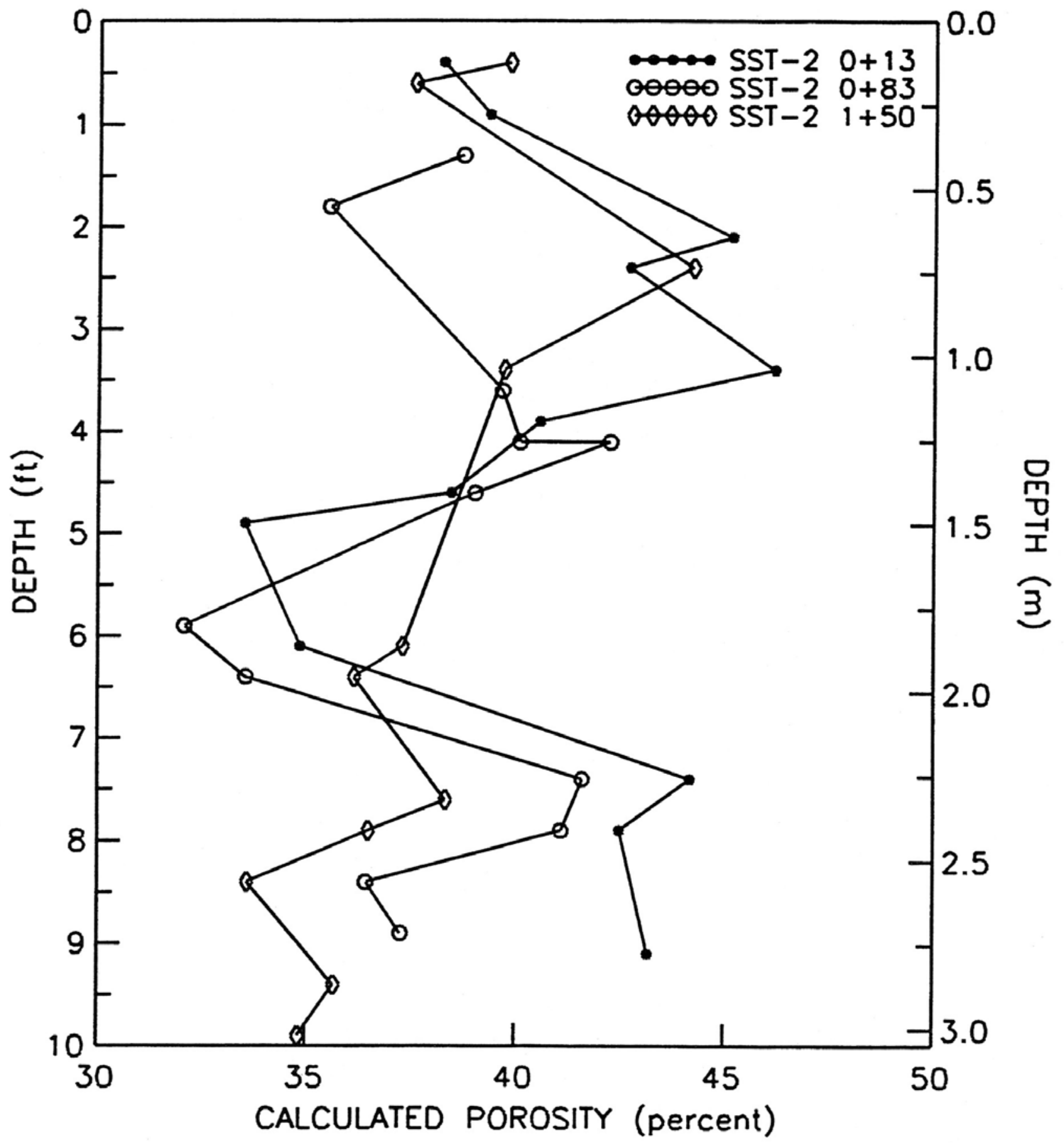

Figure 3-8

Depth Profiles of Calculated Porosity for Samples from SST-2 


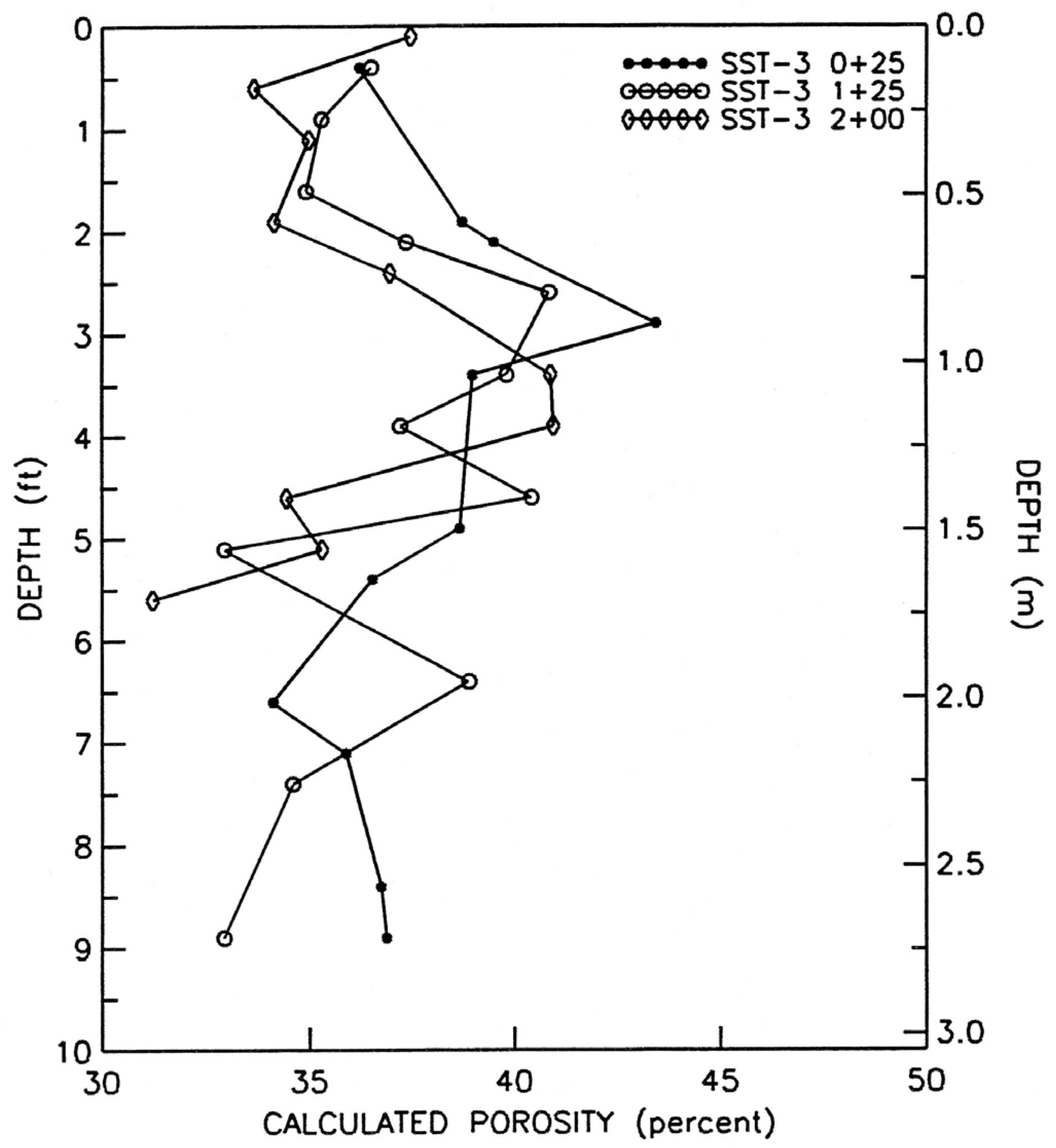

Figure 3-9

Depth Profiles of Calculated Porosity for Samples from SST-3 


\subsection{Hydrologic Properties}

Hydrologic properties are required, together with hydrologic conditions, to estimate rates of water movement and potential travel times. Hydrologic property measurements include saturated and unsaturated hydraulic conductivities and moisture retention curves. In this study unsaturated hydraulic conductivities were calculated from saturated hydraulic conductivity and moisture retention data, rather than being experimentally measured, due to the difficulty in obtaining measurements under the extremely dry in situ conditions found in the vadose zone beneath Area 5.

\subsubsection{Saturated Hydraulic Conductivity}

Saturated hydraulic conductivity measurements were conducted on the core segments from the trenches. Saturated hydraulic conductivity profiles are shown in Figures 3-10, 3-11, and 3-12. Descriptive statistics are summarized in Table 3-3 and tabular data are listed in Appendix A. The upper portions of SST-1 and SST-3 appear to be less permeable, which would be expected with finertextured material (Section 3.1). However, there are no obvious trends as a function of depth, and these values are typical of silty-sand alluvial deposits (REECo, 1993a, 1993b; BN, 2005).

\subsection{Hydrologic Conditions}

Hydrologic conditions, such as water content and water potential, are parameters that may vary over time. Water content is defined as the amount of liquid water in a specified quantity of soil. The water potentials of samples were not measured in this project.

\subsubsection{Water Content}

Water content on a weight basis (gravimetric water content) was determined for both core and grab samples. Water content on a volume basis (volumetric water content) was determined only for core samples. These data are summarized in tabular form in Appendices A and B, and descriptive statistics are presented in Table 3-3. Gravimetric water content values for core and grab samples are plotted versus depth for SST-1, SST-2, and SST-3 in Figures 3-13, 3-14, and 3-15, respectively.

Grab samples were collected as the trench was being excavated and core samples were collected at a later time. Since the core samples were collected after the trench was excavated, some drying of the samples probably occurred. Yet, the water content values are remarkably low, constant, and consistent between trenches. The only noticeable trend is an increase in water content from ground surface to approximately $1 \mathrm{~m}(3.3 \mathrm{ft})$. The upper 1 to $2 \mathrm{~m}$ ( 3.3 to $6.5 \mathrm{ft})$ of soils is a hydrologically 


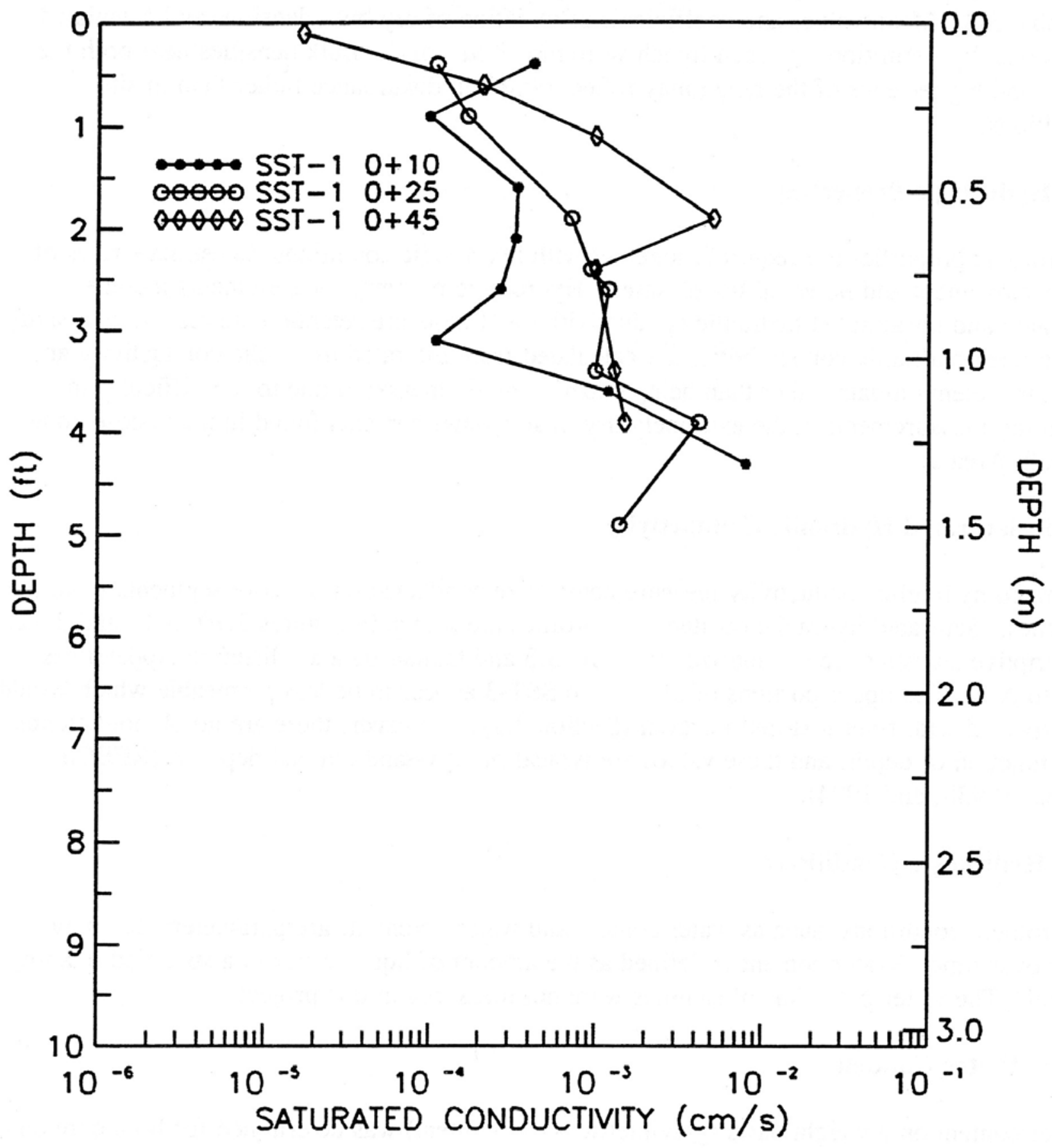

Figure 3-10

Depth Profiles of Saturated Hydraulic Conductivity for Samples from SST-1 


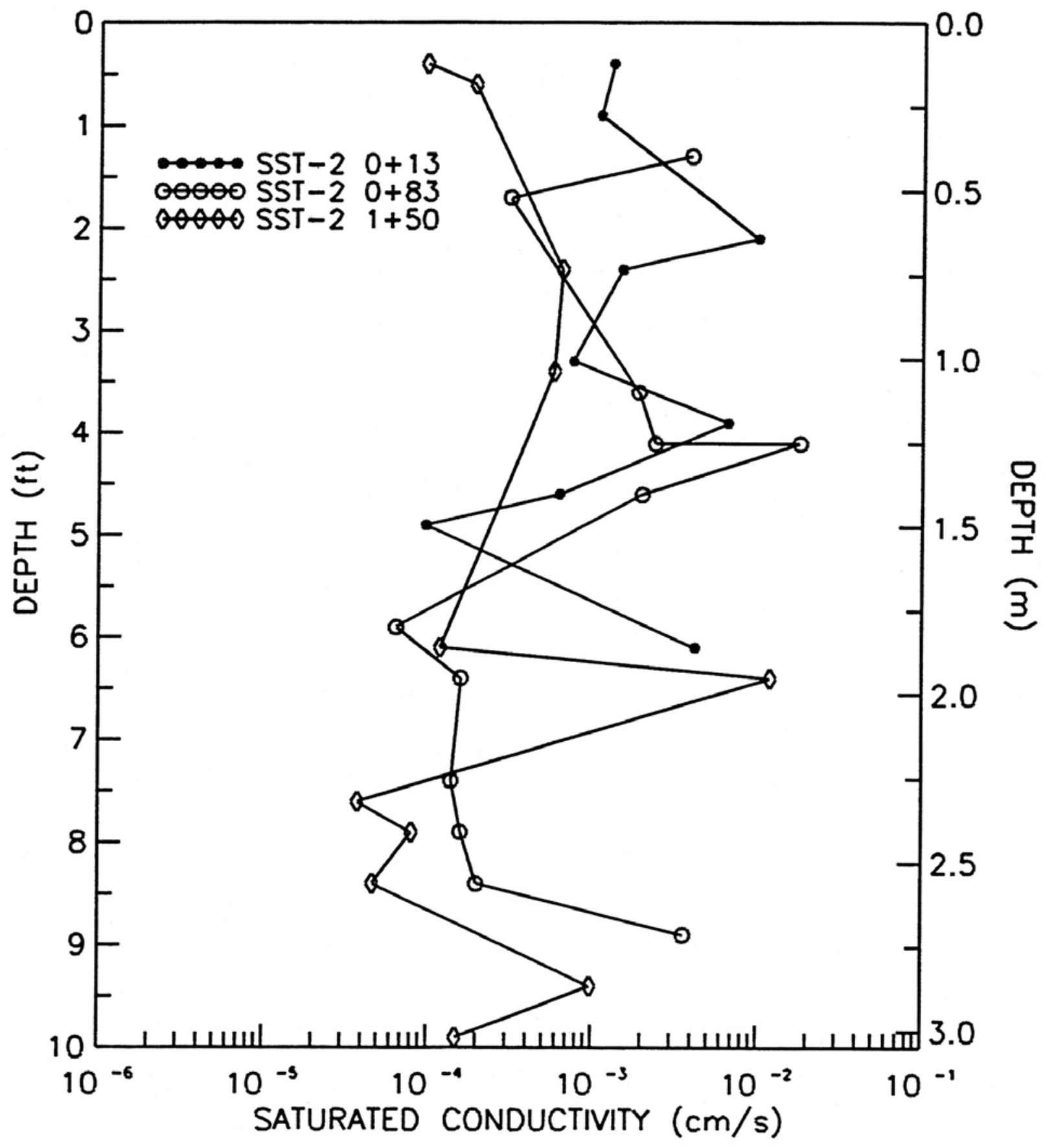

Figure 3-11

Depth Profiles of Saturated Hydraulic Conductivity for Samples from SST-2 


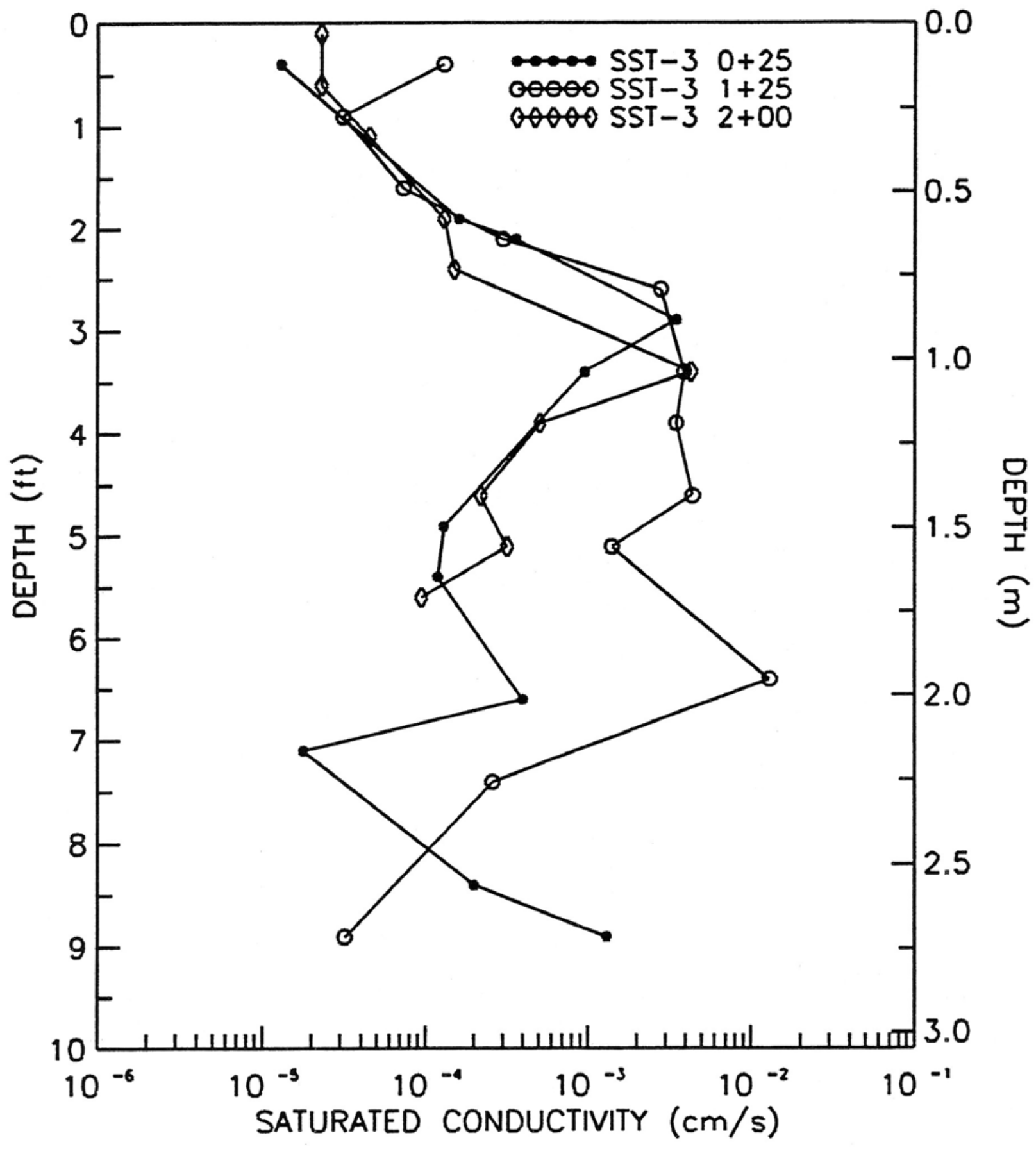

Figure 3-12

Depth Profiles of Saturated Hydraulic Conductivity for Samples from SST-3 


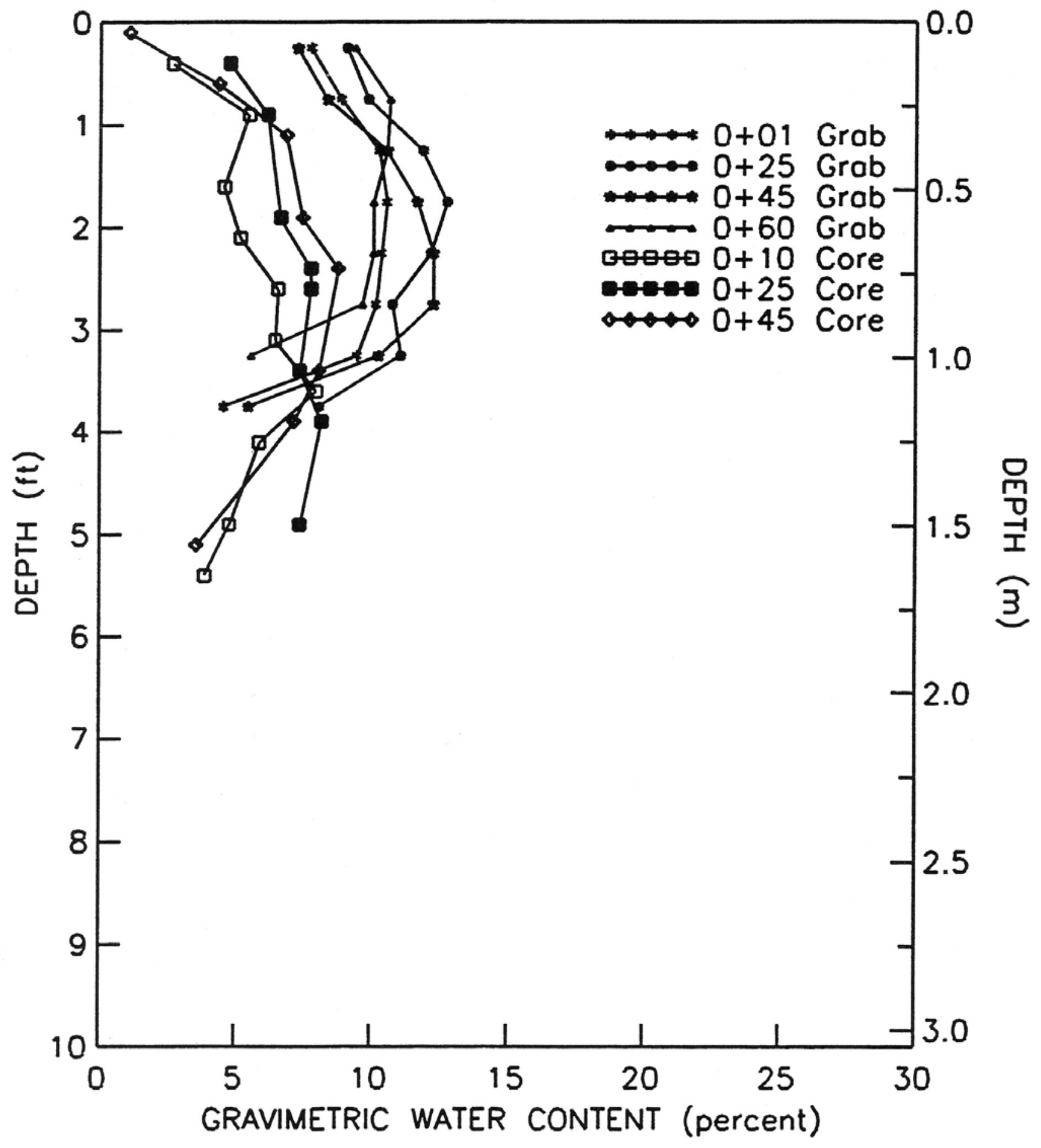

Figure 3-13

Depth Profiles of Gravimetric Water Content for Grab and Core Samples from SST-1 


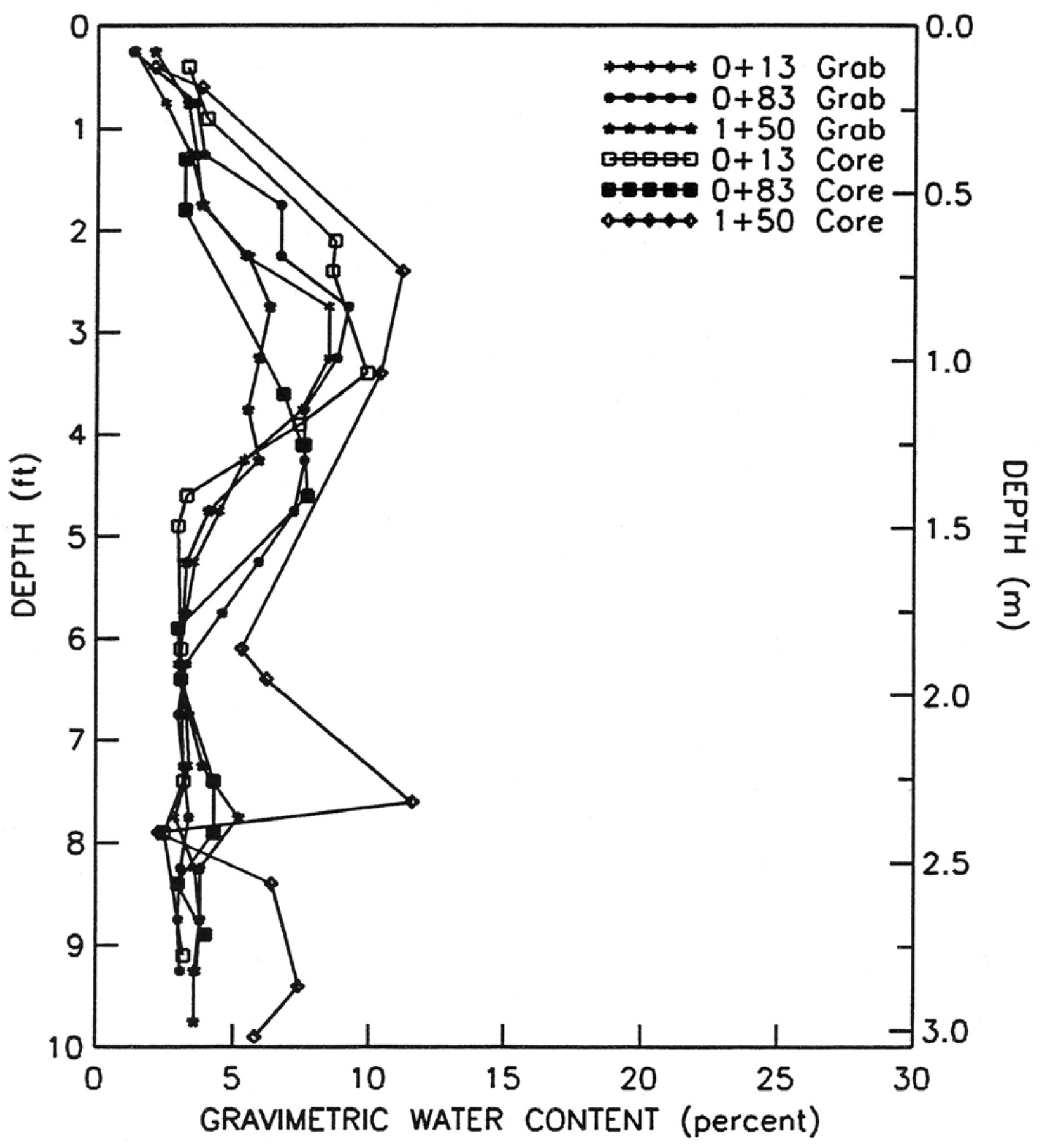

Figure 3-14

Depth Profiles of Gravimetric Water Content for Grab and Core Samples from SST-2 


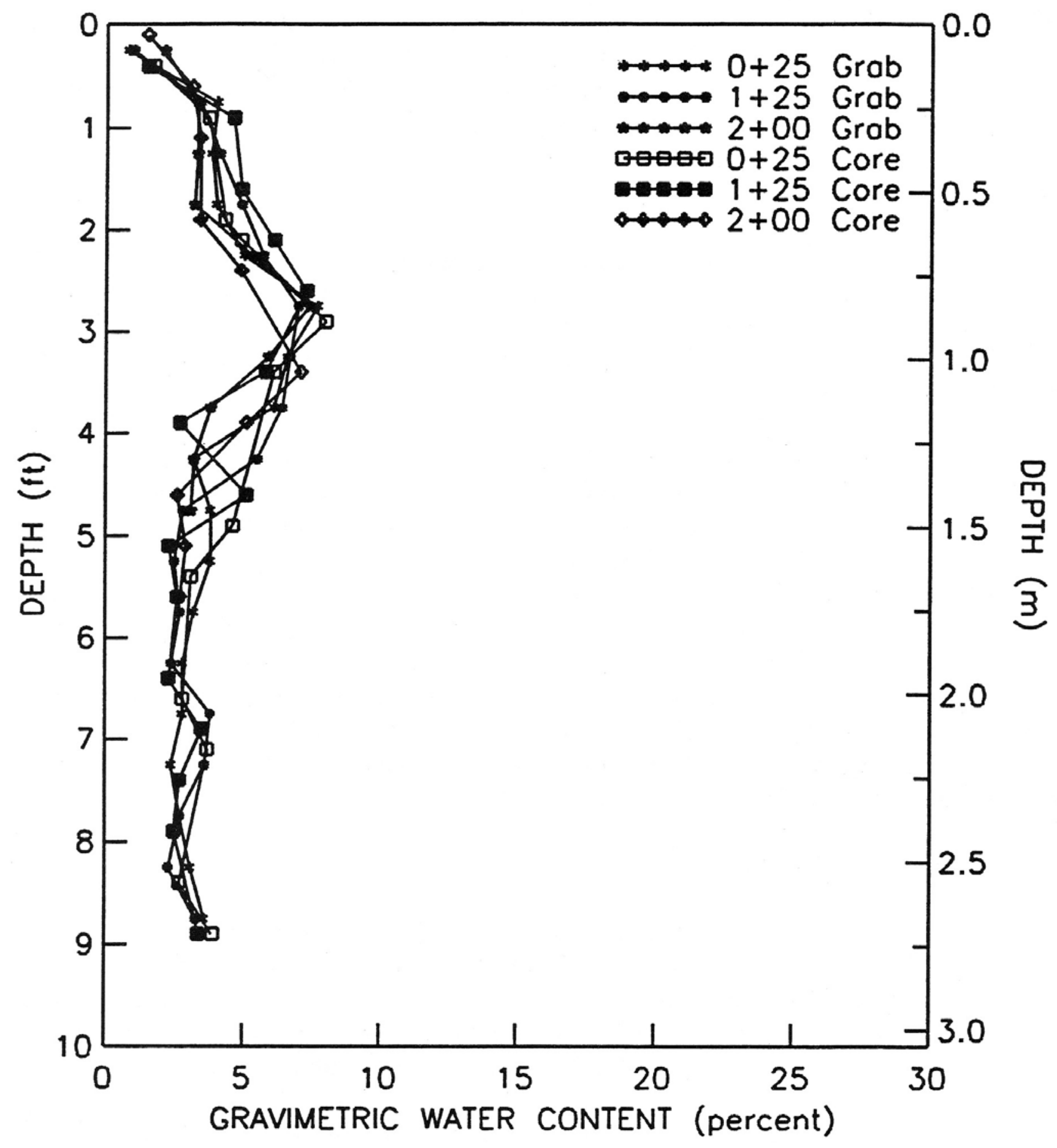

Figure 3-15

Depth Profiles of Gravimetric Water Content for Grab and Core Samples from SST-3 
active region. Here, changes in the magnitude and direction of liquid movement vary, dependent on storm water infiltration, evapotranspiration, and biota transport (NNSA/NSO, 2004).

\subsection{Carbon Content}

Depth profiles of inorganic carbon in dry soil for core samples from trenches SST-1, SST-2, and SST-3 are presented in Figures 3-16, 3-17, and 3-18, respectively. Tabular values of inorganic and organic carbon measurements, as well as calculated values of total carbon, are presented in Appendix A, and descriptive statistics for these data are summarized in Table 3-3.

The profiles show that inorganic carbon concentrations are very low (mean values are less than 1 percent by weight) and nearly constant along each vertical transect. The only noticeable trend is seen

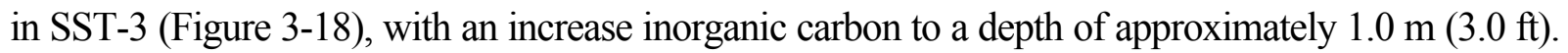
This appears to correspond to the increased water content for SST-3 (Figure 3-15) and could indicate the presence of a caliche layer below the depth sampled. The consistency seen in the depth profiles of inorganic carbon concentrations suggests that the source rock for the alluvium contains remarkably similar percentages of carbonates. This also indicates that the alluvial deposits may have originated from the same source rock. Organic carbon values were generally an order of magnitude lower and equally as constant, indicating the absence of humus accumulation.

\subsection{Cosmogenic Chlorine-36}

The radioisotope ${ }^{36} \mathrm{Cl}$ is continually produced in the upper atmosphere. Nuclear weapons tests in the South Pacific led to an increase of ${ }^{36} \mathrm{Cl}$ in the atmosphere from 1952 to 1964 . This isotope and the stable isotope $\mathrm{Cl}$, are dissolved in ionic form in precipitation and enter the ground via infiltration.

Figure 3-19 shows the ${ }^{36} \mathrm{Cl} / \mathrm{Cl}$ profile for grab samples from SST-1 at the $0+50$ location; summary statistics are given in Table 3-3; and the tabular data are listed in Appendix B.

Using the ${ }^{36} \mathrm{Cl} / \mathrm{Cl}$ ratio as an environmental tracer provides evidence that very little downward flow of liquid water is occurring in the near-surface portion of the vadose zone. 


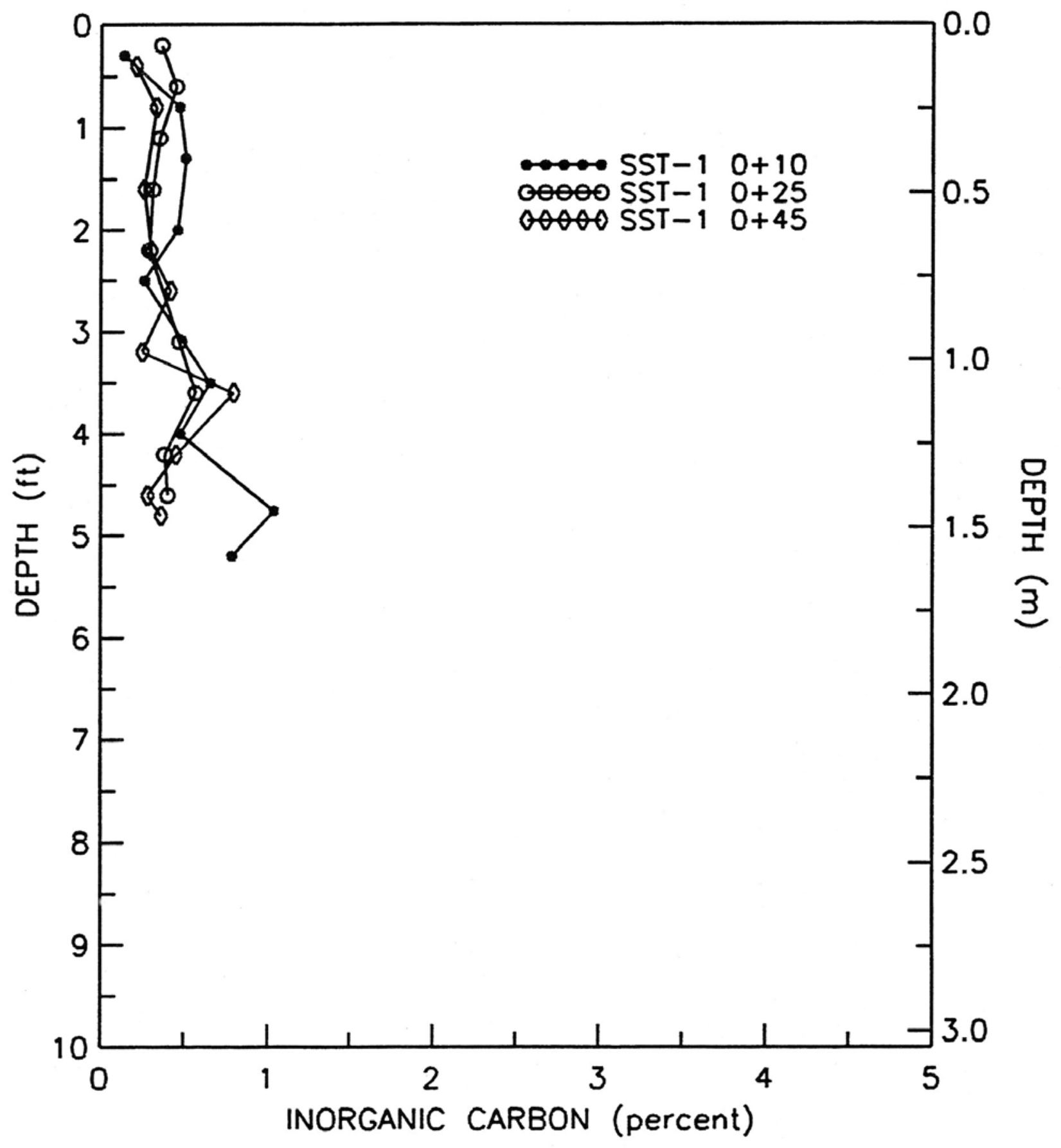

Figure 3-16

Depth Profiles of Inorganic Carbon for Core Samples from SST-1 


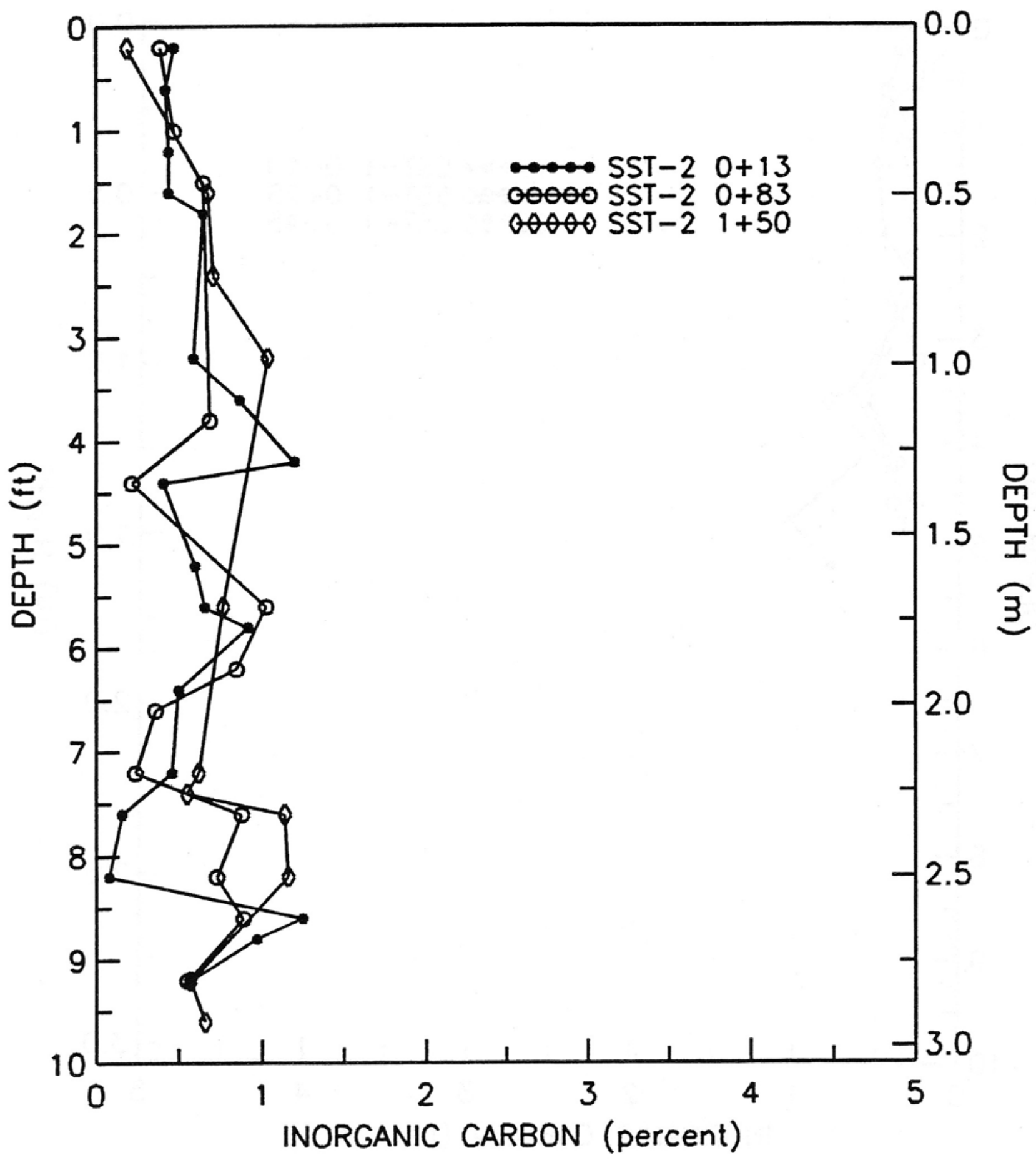

Figure 3-17

Depth Profiles of Inorganic Carbon for Core Samples from SST-2 


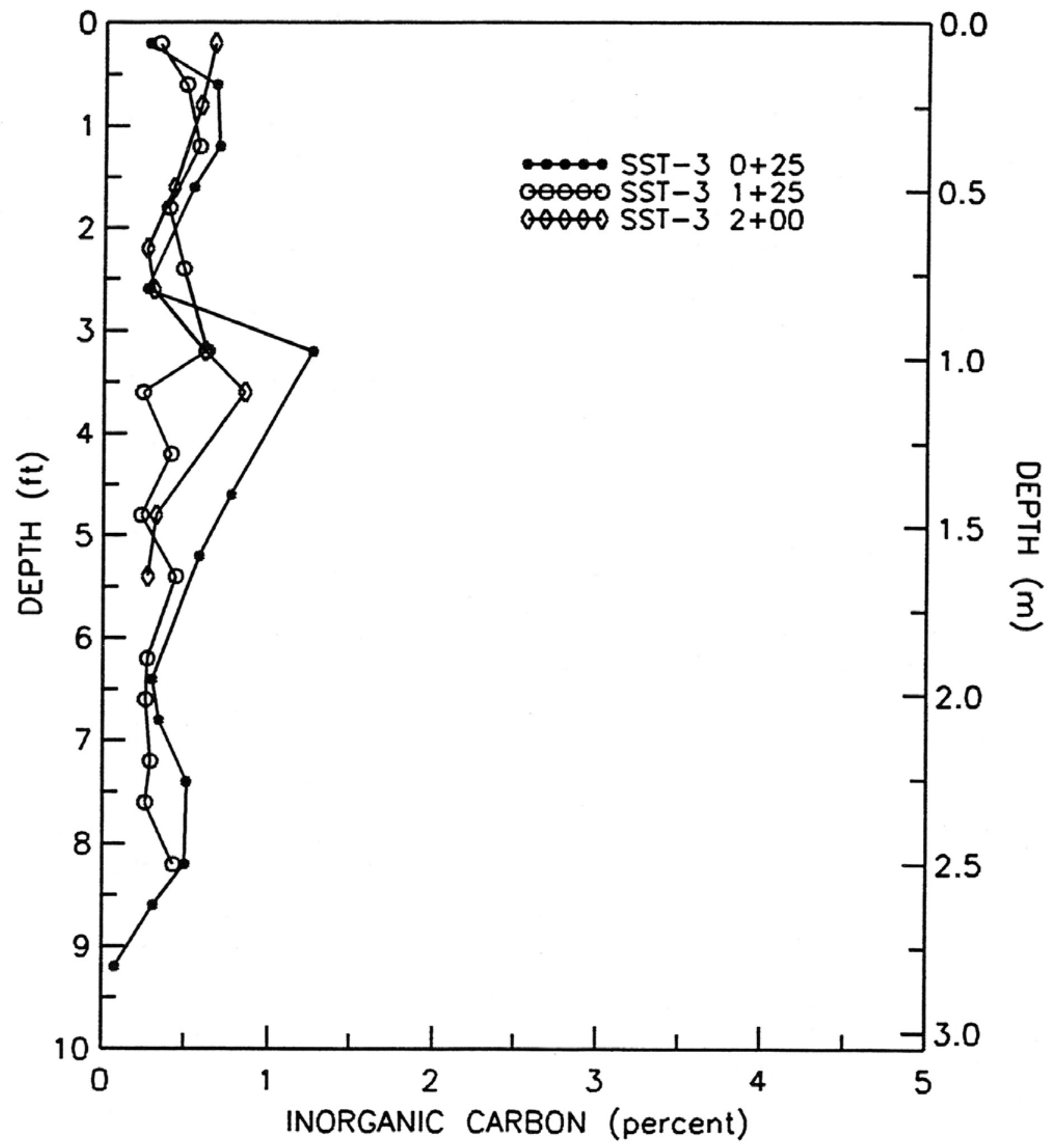

Figure 3-18

Depth Profiles of Inorganic Carbon for Core Samples from SST-3 


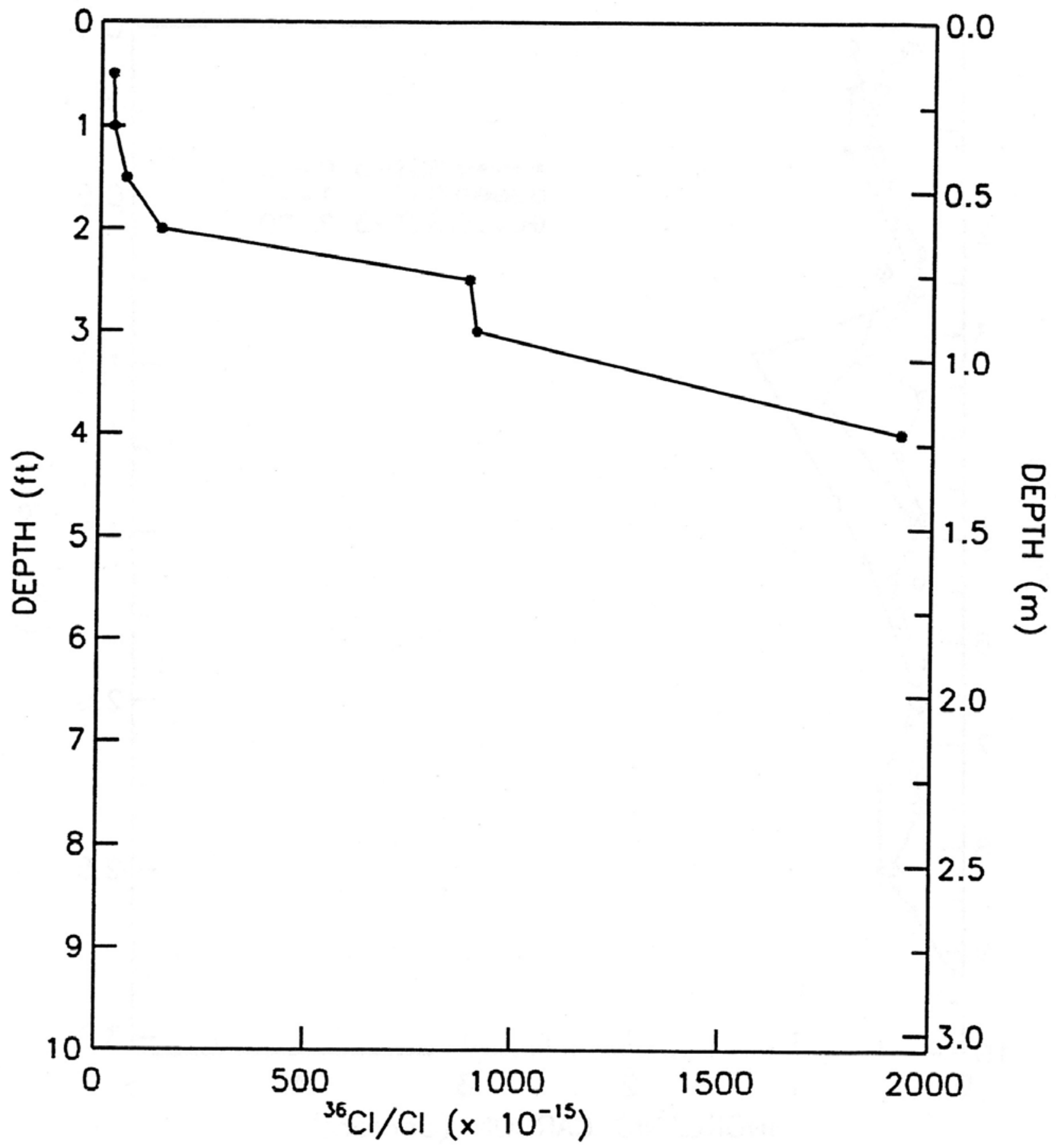

Figure 3-19

Depth Profile of ${ }^{36} \mathrm{CI} / \mathrm{CI}$ Ratios for Grab Samples from SST-1 at Location 0+50 


\subsection{Summary}

Four shallow soil trenches excavated in the vicinity of the Area 5 RWMS were sampled to characterized important physical and hydrologic parameters which can affect the movement of water in the upper few meters of undisturbed alluvium. These data were needed to support petitions for a RCRA groundwater monitoring waver and an exemption from a requirement to install liners and a leachate collection/detection system. Previous efforts at site characterization in Area 5 focused on collecting hydrogeologic data below the upper few meters of alluvium. This report described the field collection of geologic samples and the results of laboratory analyses made on these samples This report provides only qualitative analyses and preliminary interpretations.

Some of the important findings of this study are listed below.

- The alluvial deposits are relatively homogeneous with respect to particle size distribution and are primarily composed of sand with silt, some gravel, and little clay, based on field observations of texture.

- Hydrologic properties, including porosity, dry bulk density, and saturated hydraulic conductivity, are typical of sandy, near-surface alluvial materials.

- Water content values are low, constant, and consistent between trenches.

- Inorganic and organic carbon concentrations are low and constant within and between trenches.

- The physical and hydrological properties data indicate that the near-surface alluvial deposits can be considered as homogeneous material.

- Using the ${ }^{36} \mathrm{Cl} / \mathrm{Cl}$ ratio as an environmental tracer provides evidence that very little downward flow of liquid water is occurring in the near-surface portion of the vadose zone. 
This page intentionally left blank. 


\subsection{References}

Bechtel Nevada, 2005. "Site Characterization and Monitoring Data from Area 5 Pilot Wells, Nevada Test Site, Nye County, Nevada, Revision 1." Updated from unpublished document prepared in 1994 by REECo Special Projects Section, Environmental Management Division, Las Vegas, NV. DOE/NV/11718--1067. Las Vegas, NV.

Ginanni, J. M., L. J. O’Neill, D. P. Hammermeister, D. O. Blout, B. L. Dozier, M. J. Sully, K. R. Johnejack, D. F. Emer, and S. W. Tyler, 1993. Hydrogeologic Characterization of an Arid Zone Radioactive Waste Management Site. In: Proceedings of the 15th Annual U.S. Department of Energy Low-Level Radioactive Waste Management Conference. December 1-3, 1993, Phoenix, AZ. Sponsored by the National Low-Level Waste Management Program, EG\&G, Idaho, National Engineering Laboratory, Idaho Falls, ID.

Istok, J. D., D. O. Blout, L. Barker, K. R. Johnejack, and D. P. Hammermeister, 1994. Spatial Variability in Alluvium Properties at a Low-Level Nuclear Waste Site. Soil Science Society of America Journal, vol. 58, no. 4, July-August, pages 1,040-1,051.

Johnejack, K. R., D. O. Blout, M. J. Sully, D. F. Emer, and D. P. Hammermeister, 1994. Significance of Water Fluxes in a Deep Arid-Region Vadose Zone to Waste Disposal Strategies. Presented at Waste Management '94, February 27 through March 3, 1994, Tucson, AZ. Sponsored by Waste Management Symposia, Inc., Tucson, AZ.

NNSA/NSO, see U.S. Department of Energy, National Nuclear Security Administration Nevada Site Office.

O’Neill, L. J., J. M. Ginnani, D. P. Hammermeister, D. O. Blout, K. J. Sully, K. R. Johnejack, D. F. Emer, T. D. Detty, D. Schmidhoefer, D. L. Gustafson, and S. W. Tyler, 1993. A Case for Resource Conservation and Recover Act (RCRA) "No-Migration" Variance (NMV) and Land Disposal of Mixed Land Disposal Restrictions (LDR) Waste at the Nevada Test Site (NTS). Presented at Waste Management '93, February 27 through March 3, 1993, Tucson, AZ. Sponsored by Waste Management Symposia, Inc., Tucson, AZ. Pages 1,333-1,346.

REECo, see Reynolds Electrical \& Engineering Co., Inc.,

Reynolds Electrical \& Engineering Co., Inc., 1993a. Written communication prepared by REECo Special Projects Section, Environmental Management Division, for U.S. Department of Energy Nevada Operations Office, Las Vegas, NV. Subject: "Hydrogeologic Data for Existing Excavations at the Area 5 Radioactive Waste Management Site, Nevada Test Site.” Las Vegas, NV. 
Reynolds Electrical \& Engineering Co., Inc., 1993b. Written communication prepared by REECo Special Projects Section, Environmental Management Division, for U.S. Department of Energy Nevada Operations Office, Las Vegas, NV. Subject: "Hydrogeologic Data for Science Trench Boreholes at the Area 5 Radioactive Waste Management Site, Nevada Test Site, Nye County, Nevada." Las Vegas, NV.

Snyder, K. E., D. L. Gustafson, J. J. Miller, and S. E. Rawlinson, 1994. Written communication prepared for U.S. Department of Energy Nevada Operations Office, Las Vegas, NV. Subject: "Geological Components of Site Characterization and Performance Assessment for a Radioactive Waste Management Facility at the Nevada Test Site. Las Vegas, NV.

U.S. Department of Energy, National Nuclear Security Administration Nevada Site Office, 2004. Written communication prepared by Bechtel Nevada Environmental Management for NNSA/NSO, Las Vegas, NV. Subject: "Pit 3 Mixed Waste Disposal Unit, RCRA Part B Permit Application for Waste Management Activities at the Nevada Test Site, Section P.2., Revision 14, November 2004. 


\section{APPENDIX A}

Results of Laboratory Tests for Hydrologic and Material Properties and Carbon Content 


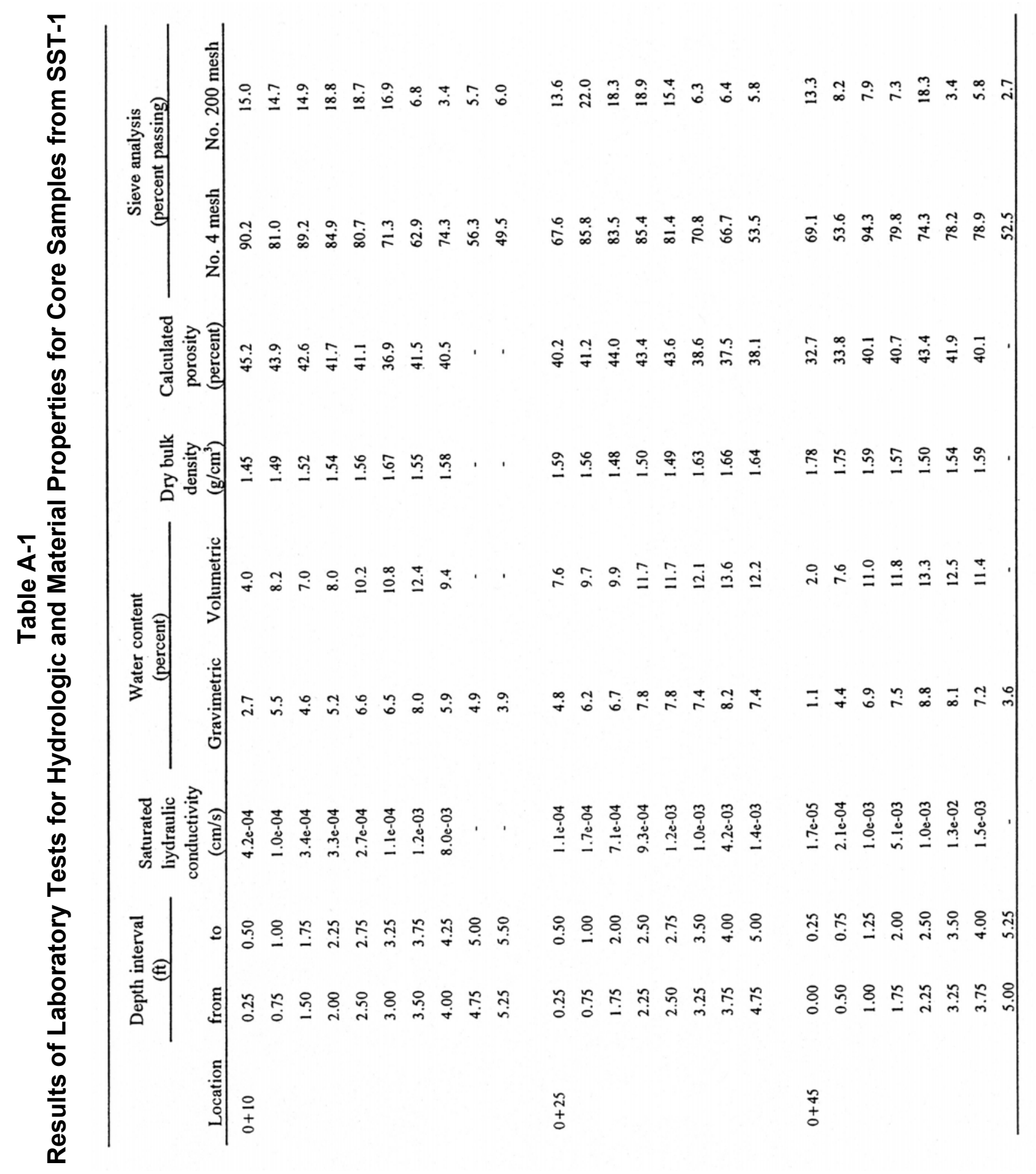




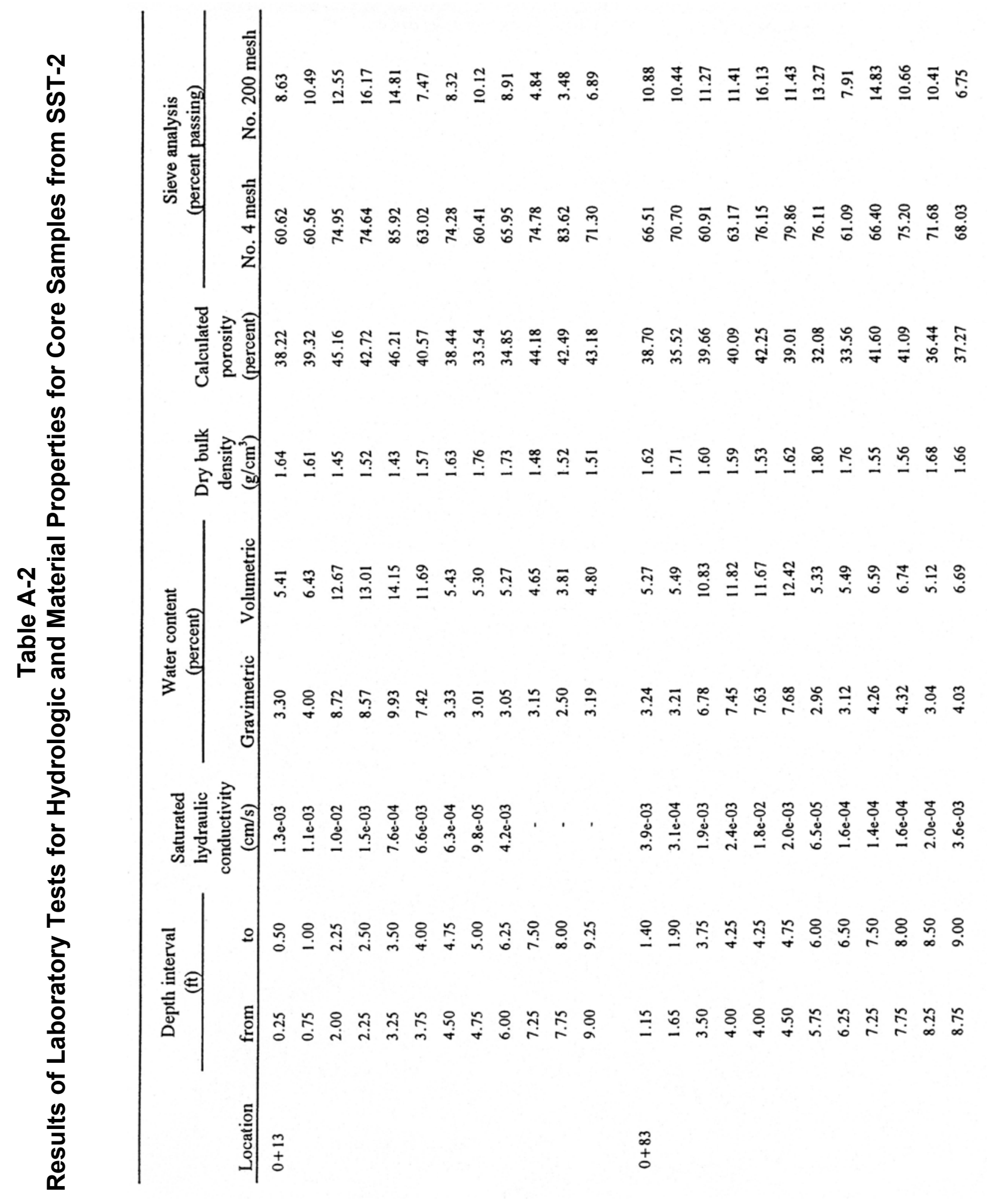




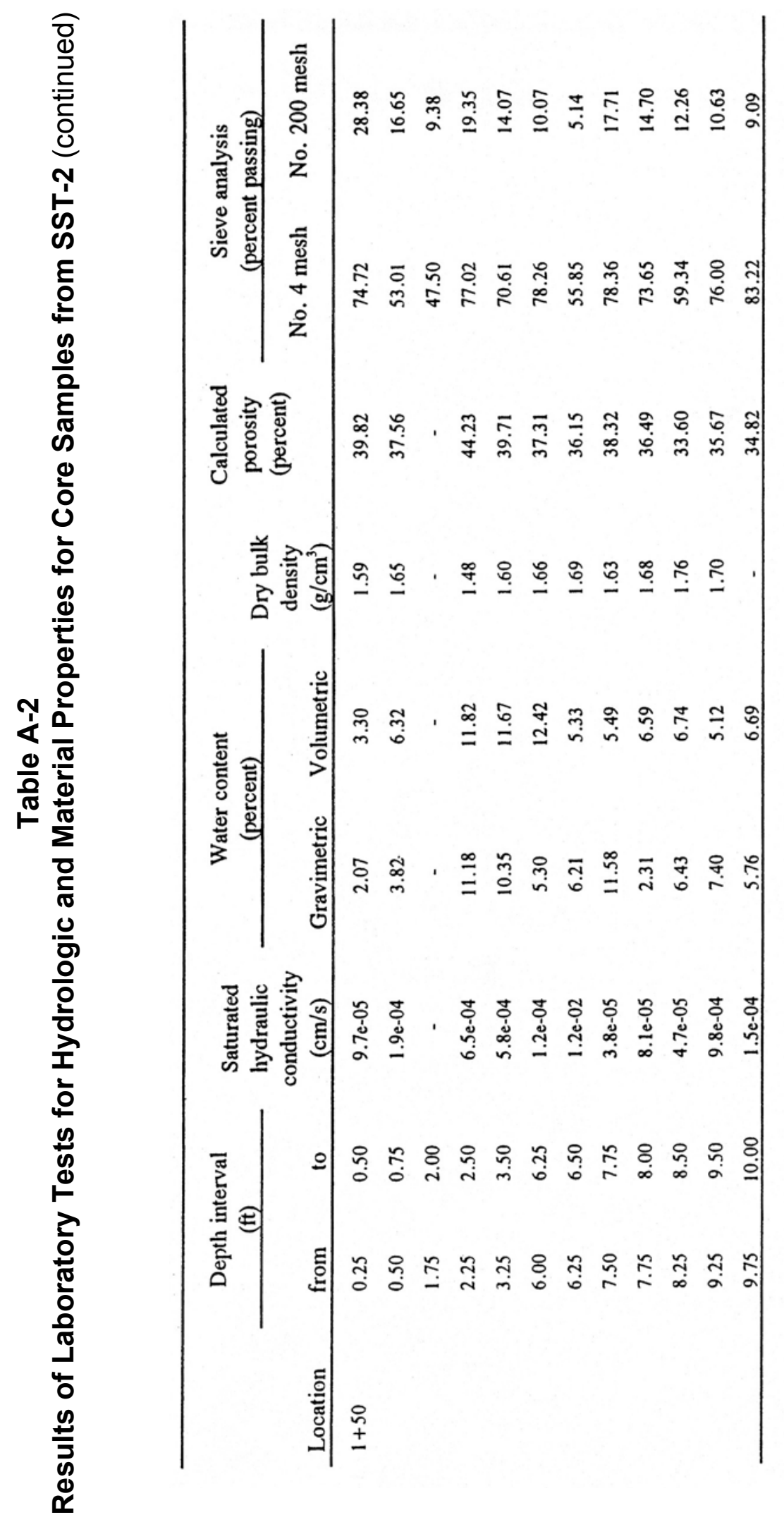




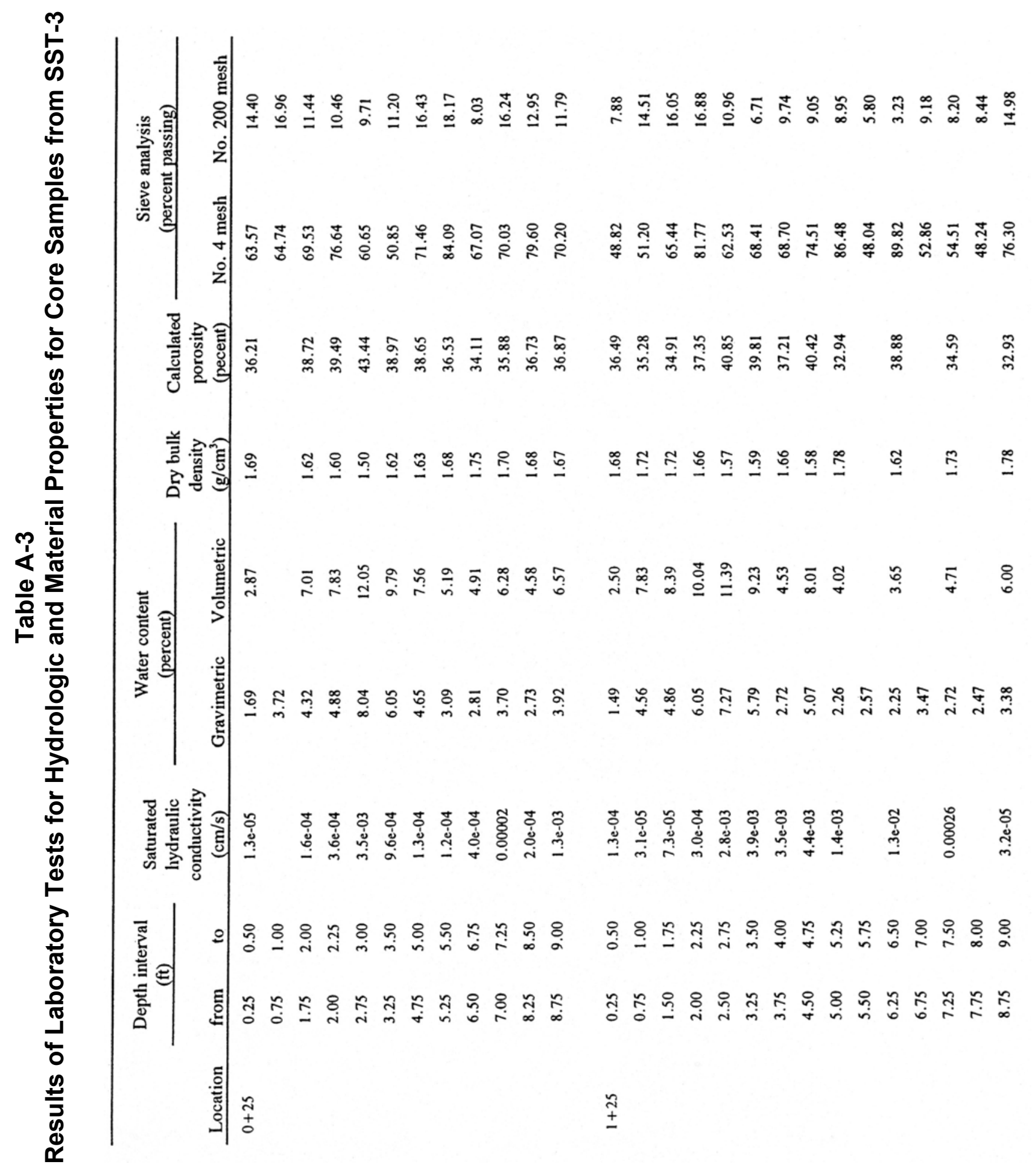




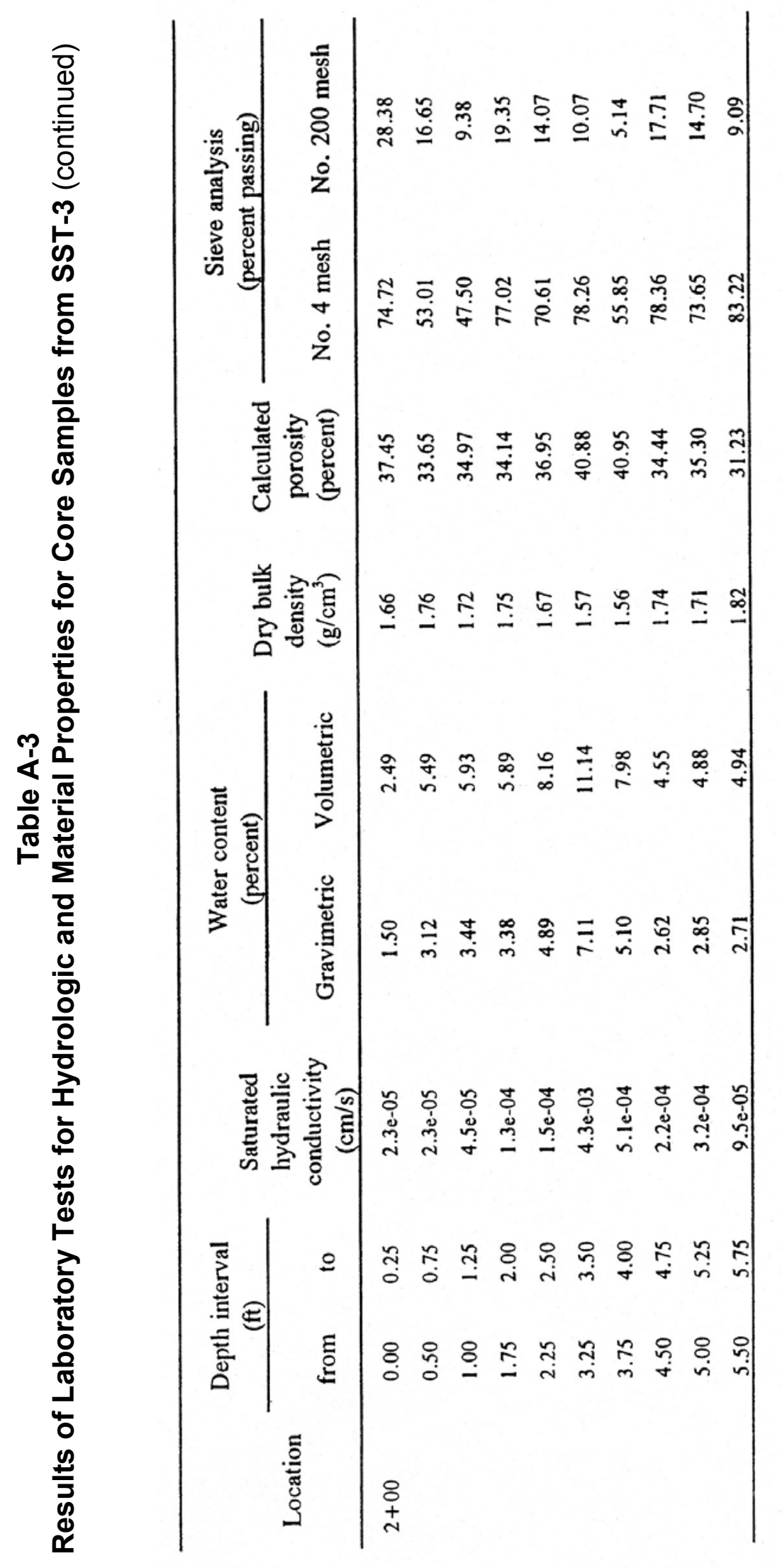


Table A-4

Results of Laboratory Tests for Carbon Content in Dry Soil for Core Samples from SST-1

\begin{tabular}{|c|c|c|c|c|c|}
\hline \multirow[b]{2}{*}{ Location } & \multicolumn{2}{|c|}{$\begin{array}{l}\text { Depth interval } \\
(\mathrm{ft})\end{array}$} & $\begin{array}{c}\text { Inorganic } \\
\text { carbon }\end{array}$ & $\begin{array}{l}\text { Organic } \\
\text { carbon }\end{array}$ & $\begin{array}{c}\text { Total } \\
\text { carbon } \\
\end{array}$ \\
\hline & from & to & \multicolumn{3}{|c|}{ (percent) } \\
\hline \multirow[t]{9}{*}{$0+10$} & 0.00 & 0.25 & 0.14 & 0.17 & 0.31 \\
\hline & 0.50 & 0.75 & 0.47 & 0.19 & 0.66 \\
\hline & 1.00 & 1.25 & 0.51 & 0.16 & 0.67 \\
\hline & 1.75 & 2.00 & 0.46 & 0.17 & 0.63 \\
\hline & 2.25 & 2.50 & 0.29 & 0.09 & 0.38 \\
\hline & 3.25 & 3.50 & 0.66 & 0.11 & 0.77 \\
\hline & 3.75 & 4.00 & 0.48 & 0.05 & 0.53 \\
\hline & 4.50 & 4.75 & 1.04 & 0.14 & 1.18 \\
\hline & 5.00 & 5.25 & 0.79 & 0.11 & 0.90 \\
\hline \multirow[t]{9}{*}{$0+25$} & 0.00 & 0.25 & 0.36 & 0.31 & 0.67 \\
\hline & 0.50 & 0.75 & 0.45 & 0.16 & 0.61 \\
\hline & 1.00 & 1.25 & 0.35 & 0.11 & 0.46 \\
\hline & 1.50 & 1.75 & 0.31 & 0.11 & 0.42 \\
\hline & 2.00 & 2.25 & 0.29 & 0.94 & 1.23 \\
\hline & 3.00 & 3.25 & 0.47 & 0.05 & 0.52 \\
\hline & 3.50 & 3.75 & 0.57 & 0.08 & 0.65 \\
\hline & 4.00 & 4.25 & 0.38 & 0.09 & 0.47 \\
\hline & 4.50 & 4.75 & 0.40 & 0.10 & 0.50 \\
\hline \multirow[t]{10}{*}{$0+45$} & 0.25 & 0.50 & 0.21 & 0.08 & 0.29 \\
\hline & 0.75 & 1.00 & 0.33 & 0.11 & 0.44 \\
\hline & 1.50 & 1.75 & 0.26 & 0.06 & 0.32 \\
\hline & 2.00 & 2.25 & 0.30 & 0.09 & 0.39 \\
\hline & 2.50 & 2.75 & 0.42 & 0.09 & 0.51 \\
\hline & 3.00 & 3.25 & 0.25 & 0.05 & 0.30 \\
\hline & 3.50 & 3.75 & 0.80 & 0.06 & 0.86 \\
\hline & 4.00 & 4.25 & 0.45 & 0.06 & 0.51 \\
\hline & 4.50 & 4.75 & 0.28 & 0.05 & 0.33 \\
\hline & 4.75 & 5.00 & 0.36 & 0.02 & 0.38 \\
\hline
\end{tabular}


Table A-5

Results of Laboratory Tests for Carbon Content in Dry Soil for

Core Samples from SST-2

\begin{tabular}{|c|c|c|c|c|c|}
\hline \multirow[b]{2}{*}{ Location } & \multicolumn{2}{|c|}{$\begin{array}{l}\text { Depth interval } \\
\text { (ft) }\end{array}$} & $\begin{array}{c}\text { Inorganic } \\
\text { carbon }\end{array}$ & $\begin{array}{l}\begin{array}{l}\text { Organic } \\
\text { carbon }\end{array} \\
\end{array}$ & $\begin{array}{c}\text { Total } \\
\text { carbon }\end{array}$ \\
\hline & from & to & \multicolumn{3}{|c|}{ (percent) } \\
\hline \multirow[t]{19}{*}{$0+13$} & 0.00 & 0.25 & 0.47 & 0.20 & 0.67 \\
\hline & 0.50 & 0.75 & 0.42 & 0.11 & 0.53 \\
\hline & 1.00 & 1.25 & 0.44 & 0.16 & 0.60 \\
\hline & 1.50 & 1.75 & 0.44 & 0.08 & 0.52 \\
\hline & 1.75 & 2.00 & 0.65 & 0.09 & 0.74 \\
\hline & 3.00 & 3.25 & 0.59 & 0.13 & 0.72 \\
\hline & 3.50 & 3.75 & 0.87 & 0.21 & 1.08 \\
\hline & 4.00 & 4.25 & 1.20 & 0.16 & 1.36 \\
\hline & 4.25 & 4.50 & 0.41 & 0.05 & 0.46 \\
\hline & 5.00 & 5.25 & 0.60 & 0.05 & 0.65 \\
\hline & 5.50 & 5.75 & 0.66 & 0.13 & 0.79 \\
\hline & 5.75 & 6.00 & 0.92 & 0.17 & 1.09 \\
\hline & 6.25 & 6.50 & 0.50 & 0.05 & 0.55 \\
\hline & 7.00 & 7.25 & 0.46 & 0.04 & 0.50 \\
\hline & 7.50 & 7.75 & 0.16 & 0.02 & 0.18 \\
\hline & 8.00 & 8.25 & 0.08 & 0.01 & 0.09 \\
\hline & 8.50 & 8.75 & 1.25 & 0.08 & 1.33 \\
\hline & 8.75 & 9.00 & 0.97 & 0.05 & 1.02 \\
\hline & 9.25 & 9.50 & 0.57 & 0.04 & 0.61 \\
\hline \multirow[t]{13}{*}{$0+83$} & 0.00 & 0.25 & 0.39 & 0.65 & 1.04 \\
\hline & 0.90 & 1.15 & 0.47 & 0.56 & 1.03 \\
\hline & 1.40 & 1.65 & 0.65 & 0.15 & 0.80 \\
\hline & 3.75 & 4.00 & 0.69 & 0.11 & 0.80 \\
\hline & 4.25 & 4.50 & 0.22 & 0.04 & 0.26 \\
\hline & 5.50 & 5.75 & 1.03 & 0.10 & 1.13 \\
\hline & 6.00 & 6.25 & 0.85 & 0.06 & 0.91 \\
\hline & 6.50 & 6.75 & 0.36 & 0.03 & 0.39 \\
\hline & 7.00 & 7.25 & 0.24 & 0.04 & 0.28 \\
\hline & 7.50 & 7.75 & 0.88 & 0.07 & 0.95 \\
\hline & 8.00 & 8.25 & 0.73 & 0.06 & 0.79 \\
\hline & 8.50 & 8.75 & 0.89 & 0.08 & 0.97 \\
\hline & 9.00 & 9.25 & 0.55 & 0.04 & 0.59 \\
\hline \multirow[t]{11}{*}{$1+50$} & 0.00 & 0.25 & 0.19 & 0.24 & 0.43 \\
\hline & 1.50 & 1.75 & 0.68 & 0.16 & 0.84 \\
\hline & 2.25 & 2.50 & 0.71 & 0.13 & 0.84 \\
\hline & 3.00 & 3.25 & 1.04 & 0.14 & 1.18 \\
\hline & 5.50 & 5.75 & 0.77 & 0.10 & 0.87 \\
\hline & 7.00 & 7.25 & 0.62 & 0.07 & 0.69 \\
\hline & 7.25 & 7.50 & 0.55 & 0.05 & 0.60 \\
\hline & 7.50 & 7.75 & 1.14 & 0.12 & 1.26 \\
\hline & 8.00 & 8.25 & 1.16 & 0.11 & 1.27 \\
\hline & 9.00 & 9.25 & 0.57 & 0.06 & 0.63 \\
\hline & 9.50 & 9.75 & 0.66 & 0.05 & 0.71 \\
\hline
\end{tabular}


Table A-6

Results of Laboratory Tests for Carbon Content in Dry Soil for Core Samples from SST-3

\begin{tabular}{|c|c|c|c|c|c|}
\hline \multirow[b]{2}{*}{ Location } & \multicolumn{2}{|c|}{$\begin{array}{l}\text { Depth interval } \\
(\mathrm{ft})\end{array}$} & $\begin{array}{c}\text { Inorganic } \\
\text { carbon }\end{array}$ & $\begin{array}{l}\text { Organic } \\
\text { carbon }\end{array}$ & $\begin{array}{c}\text { Total } \\
\text { carbon }\end{array}$ \\
\hline & from & to & \multicolumn{3}{|c|}{ (percent) } \\
\hline $0+25$ & $\begin{array}{l}0.00 \\
0.50 \\
1.00 \\
1.50 \\
2.50 \\
3.00 \\
4.50 \\
5.00 \\
6.25 \\
6.75 \\
7.25 \\
8.00 \\
8.50 \\
9.00\end{array}$ & $\begin{array}{l}0.25 \\
0.75 \\
1.25 \\
1.75 \\
2.75 \\
3.25 \\
4.75 \\
5.25 \\
6.50 \\
7.00 \\
7.50 \\
8.25 \\
8.75 \\
9.25\end{array}$ & $\begin{array}{l}0.27 \\
0.67 \\
0.69 \\
0.54 \\
0.26 \\
1.26 \\
0.77 \\
0.58 \\
0.30 \\
0.34 \\
0.51 \\
0.50 \\
0.31 \\
0.08\end{array}$ & $\begin{array}{l}0.15 \\
0.31 \\
0.22 \\
0.11 \\
0.08 \\
0.11 \\
0.06 \\
0.05 \\
0.04 \\
0.03 \\
0.05 \\
0.04 \\
0.04 \\
0.02\end{array}$ & $\begin{array}{l}0.42 \\
0.98 \\
0.91 \\
0.65 \\
0.34 \\
1.37 \\
0.83 \\
0.63 \\
0.34 \\
0.37 \\
0.56 \\
0.54 \\
0.35 \\
0.11\end{array}$ \\
\hline $1+25$ & $\begin{array}{l}0.00 \\
0.50 \\
1.00 \\
1.75 \\
2.25 \\
3.00 \\
3.50 \\
4.00 \\
4.75 \\
5.25 \\
6.00 \\
6.50 \\
7.00 \\
7.50 \\
8.00 \\
8.50\end{array}$ & $\begin{array}{l}0.25 \\
0.75 \\
1.25 \\
2.00 \\
2.50 \\
3.25 \\
3.75 \\
4.25 \\
5.00 \\
5.50 \\
6.25 \\
6.75 \\
7.25 \\
7.75 \\
8.25 \\
8.75\end{array}$ & $\begin{array}{l}0.33 \\
0.49 \\
0.57 \\
0.39 \\
0.48 \\
0.62 \\
0.24 \\
0.41 \\
0.23 \\
0.44 \\
0.27 \\
0.26 \\
0.29 \\
0.26 \\
0.43\end{array}$ & $\begin{array}{l}0.14 \\
0.14 \\
0.14 \\
0.07 \\
0.05 \\
0.08 \\
0.03 \\
0.08 \\
0.06 \\
0.04 \\
0.04 \\
0.03 \\
0.04 \\
0.04 \\
0.04 \\
0.01\end{array}$ & $\begin{array}{l}0.47 \\
0.63 \\
0.71 \\
0.46 \\
0.53 \\
0.70 \\
0.27 \\
0.49 \\
0.29 \\
0.48 \\
0.31 \\
0.29 \\
0.33 \\
0.30 \\
0.47\end{array}$ \\
\hline $2+00$ & $\begin{array}{l}0.00 \\
0.75 \\
1.50 \\
2.00 \\
2.50 \\
3.00 \\
3.50 \\
4.75 \\
5.25 \\
\end{array}$ & $\begin{array}{l}0.25 \\
1.00 \\
1.75 \\
2.25 \\
2.75 \\
3.25 \\
3.75 \\
5.00 \\
5.50 \\
\end{array}$ & $\begin{array}{l}0.66 \\
0.58 \\
0.42 \\
0.26 \\
0.30 \\
0.61 \\
0.85 \\
0.32 \\
0.27 \\
\end{array}$ & $\begin{array}{l}0.18 \\
0.15 \\
0.14 \\
0.06 \\
0.08 \\
0.13 \\
0.16 \\
0.07 \\
0.06 \\
\end{array}$ & $\begin{array}{l}0.84 \\
0.73 \\
0.56 \\
0.32 \\
0.38 \\
0.74 \\
1.01 \\
0.39 \\
0.33 \\
\end{array}$ \\
\hline
\end{tabular}




\section{APPENDIX B}

\section{Results of Laboratory Tests for Gravimetric Water Content}

and Chlorine-36 


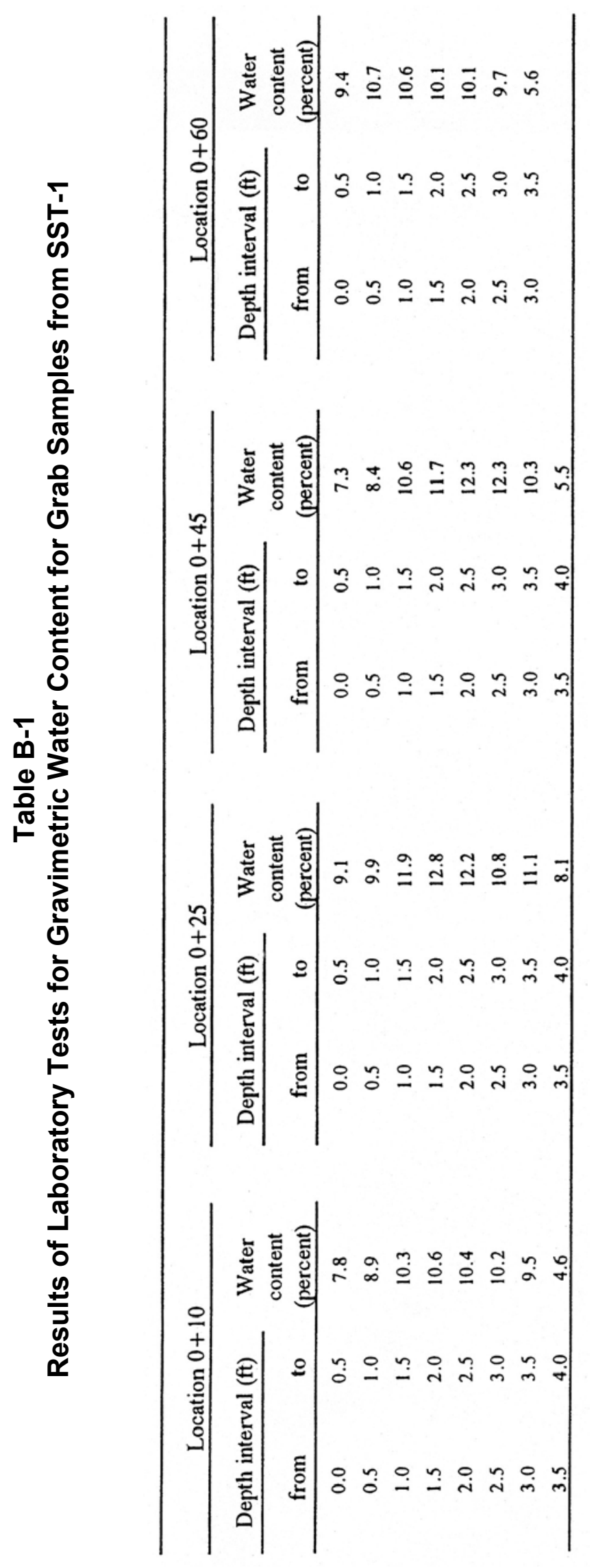

B-1 
Table B-2

Results of Laboratory Tests for Gravimetric Water Content for

Grab Samples from SST-2

\begin{tabular}{|c|c|c|c|c|c|c|c|c|}
\hline \multicolumn{3}{|c|}{ Location $0+13$} & \multicolumn{3}{|c|}{ Location $0+83$} & \multicolumn{3}{|c|}{ Location $1+50$} \\
\hline \multicolumn{2}{|c|}{ Depth interval (ft) } & \multirow{2}{*}{$\begin{array}{c}\text { Water } \\
\text { content } \\
\text { (percent) }\end{array}$} & \multicolumn{2}{|c|}{ Depth interval (ft) } & \multirow{2}{*}{$\begin{array}{c}\text { Water } \\
\text { content } \\
\text { (percent) }\end{array}$} & \multicolumn{2}{|c|}{ Depth interval (ft) } & \multirow{2}{*}{$\begin{array}{c}\text { Water } \\
\text { content } \\
\text { (percent) } \\
\end{array}$} \\
\hline from & to & & from & to & & from & to & \\
\hline 0.0 & 0.5 & 1.4 & 0.0 & 0.5 & 1.3 & 0.0 & 0.5 & 2.1 \\
\hline 0.5 & 1.0 & 2.5 & 0.5 & 1.0 & 3.6 & 0.5 & 1.0 & 3.3 \\
\hline 1.0 & 1.5 & 3.4 & 1.0 & 1.5 & 3.9 & 1.0 & 1.5 & 3.6 \\
\hline 1.5 & 2.0 & 3.9 & 1.5 & 2.0 & 6.7 & 1.5 & 2.0 & 3.8 \\
\hline 2.0 & 2.5 & 5.4 & 2.0 & 2.5 & 6.7 & 2.0 & 2.5 & 5.5 \\
\hline 2.5 & 3.0 & 8.5 & 2.5 & 3.0 & 9.2 & 2.5 & 3.0 & 6.3 \\
\hline 3.0 & 3.5 & 8.5 & 3.0 & 3.5 & 8.8 & 3.0 & 3.5 & 5.9 \\
\hline 3.5 & 4.0 & 7.5 & 3.5 & 4.0 & 7.6 & 3.5 & 4.0 & 5.5 \\
\hline 4.0 & 4.5 & 5.4 & 4.0 & 4.5 & 7.6 & 4.0 & 4.5 & 5.9 \\
\hline 4.5 & 5.0 & 4.5 & 4.5 & 5.0 & 7.2 & 4.5 & 5.0 & 4.1 \\
\hline 5.0 & 5.5 & 3.6 & 5.0 & 5.5 & 5.9 & 5.0 & 5.5 & 3.3 \\
\hline 5.5 & 6.0 & 3.3 & 5.5 & 6.0 & 4.6 & 5.5 & 6.0 & 3.2 \\
\hline 6.0 & 6.5 & 3.0 & 6.0 & 6.5 & 3.3 & 6.0 & 6.5 & 3.1 \\
\hline 6.5 & 7.0 & 3.3 & 6.5 & 7.0 & 3.0 & 6.5 & 7.0 & 3.4 \\
\hline 7.0 & 7.5 & 3.4 & 7.0 & 7.5 & 3.2 & 7.0 & 7.5 & 3.9 \\
\hline 7.5 & 8.0 & 2.9 & 7.5 & 8.0 & 3.4 & 7.5 & 8.0 & 5.2 \\
\hline 8.0 & 8.5 & 3.6 & 8.0 & 8.5 & 3.1 & 8.0 & 8.5 & 3.8 \\
\hline 8.5 & 9.0 & 3.8 & 8.5 & 9.0 & 3.0 & 8.5 & 9.0 & 3.8 \\
\hline \multirow[t]{2}{*}{9.0} & 9.5 & 3.7 & 9.0 & 9.5 & 3.1 & 9.0 & 9.5 & 3.6 \\
\hline & & & & & & 9.5 & 10.0 & 3.6 \\
\hline
\end{tabular}


Table B-3

Results of Laboratory Tests for Gravimetric Water Conten

for Grab Samples from SST-3

\begin{tabular}{|c|c|c|c|c|c|c|c|c|}
\hline \multicolumn{3}{|c|}{ Location $0+25$} & \multicolumn{3}{|c|}{ Location $1+25$} & \multicolumn{3}{|c|}{ Location $2+00$} \\
\hline \multicolumn{2}{|c|}{ Depth interval (ft) } & \multirow{2}{*}{$\begin{array}{l}\text { Water } \\
\text { content } \\
\text { (percent) }\end{array}$} & \multicolumn{2}{|c|}{ Depth interval (ft) } & \multirow{2}{*}{$\begin{array}{c}\text { Water } \\
\text { content } \\
\text { (percent) }\end{array}$} & \multicolumn{2}{|c|}{$\begin{array}{c}\text { Depth interval } \\
\text { (ft) }\end{array}$} & \multirow{2}{*}{$\begin{array}{c}\text { Water } \\
\text { content } \\
\text { (percent) }\end{array}$} \\
\hline from & to & & from & to & & from & to & \\
\hline 0.0 & 0.5 & 0.8 & 0.0 & 0.5 & 1.0 & 0.0 & 0.5 & 2.1 \\
\hline 0.5 & 1.0 & 4.0 & 0.5 & 1.0 & 3.4 & 0.5 & 1.0 & 3.3 \\
\hline 1.0 & 1.5 & 3.8 & 1.0 & 1.5 & 4.1 & 1.0 & 1.5 & 3.3 \\
\hline 1.5 & 2.0 & 4.0 & 1.5 & 2.0 & 4.9 & 1.5 & 2.0 & 3.2 \\
\hline 2.0 & 2.5 & 5.0 & 2.0 & 2.5 & 5.7 & 2.0 & 2.5 & 5.3 \\
\hline 2.5 & 3.0 & 7.7 & 2.5 & 3.0 & 7.0 & 2.5 & 3.0 & 7.4 \\
\hline 3.0 & 3.5 & 6.6 & 3.0 & 3.5 & 6.7 & 3.0 & 3.5 & 5.9 \\
\hline 3.5 & 4.0 & 6.1 & 3.5 & 4.0 & 6.4 & 3.5 & 4.0 & 3.8 \\
\hline 4.0 & 4.5 & 3.2 & 4.0 & 4.5 & 5.5 & 4.0 & 4.5 & 3.2 \\
\hline 4.5 & 5.0 & 3.8 & 4.5 & 5.0 & 2.8 & 4.5 & 5.0 & 3.1 \\
\hline 5.0 & 5.5 & 3.8 & 5.0 & 5.5 & 2.5 & & & \\
\hline 5.5 & 6.0 & 3.2 & 5.5 & 6.0 & 2.7 & & & \\
\hline 6.0 & 6.5 & 2.8 & 6.0 & 6.5 & 2.4 & & & \\
\hline 6.5 & 7.0 & 2.8 & 6.5 & 7.0 & 3.8 & & & \\
\hline 7.0 & 7.5 & 2.4 & 7.0 & 7.5 & 3.6 & & & \\
\hline 7.5 & 8.0 & 2.7 & 7.5 & 8.0 & 2.7 & & & \\
\hline 8.0 & 8.5 & 3.1 & 8.0 & 8.5 & 2.3 & & & \\
\hline 8.5 & 9.0 & 3.6 & 8.5 & 9.0 & 3.3 & & & \\
\hline
\end{tabular}




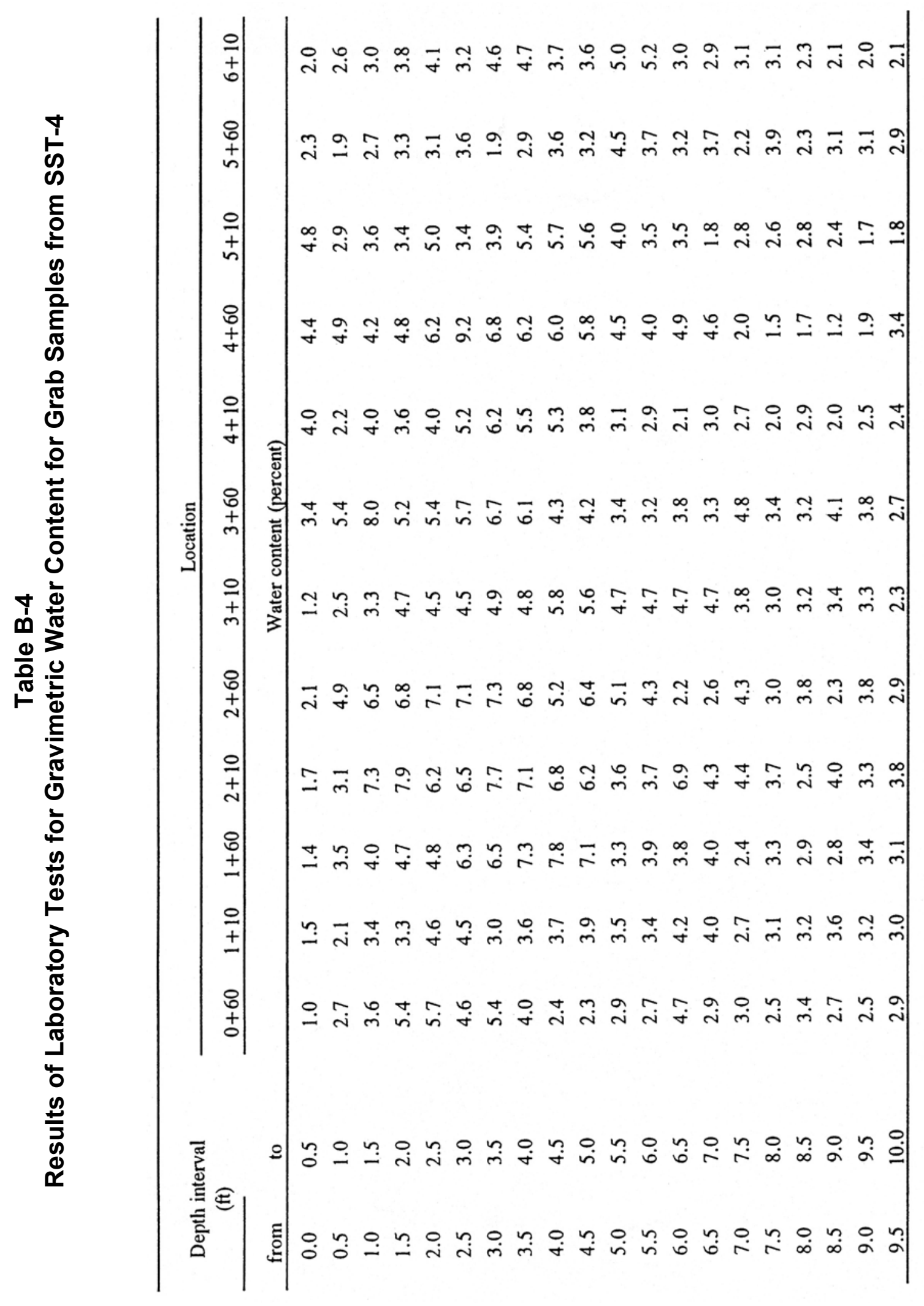


Table B-5

Results of Laboratory Tests for Chlorine-36 for Grab Samples from SST-1

\begin{tabular}{cc}
\hline $\begin{array}{c}\text { Depth } \\
\text { (feet) }\end{array}$ & $\begin{array}{c}{ }^{36} \mathrm{Cl} / \mathrm{Cl} \\
\left(\times 10^{-15}\right)\end{array}$ \\
\hline 0.5 & 29.15 \\
1.0 & 32.67 \\
1.5 & 62.73 \\
2.0 & 147.20 \\
2.5 & 890.20 \\
3.0 & 908.50 \\
4.0 & $1,926.00$ \\
\hline
\end{tabular}


This page intentionally left blank. 


\section{U.S. Department of Energy}

\section{Distribution List}

Jhon Carilli

Waste Management Division

U.S. Department of Energy

National Nuclear Security Administration

Nevada Site Office

P.O. Box 98518, M/S 505

Las Vegas, NV 89193-8518

B. M. Crowe

Apogen Technologies

U.S. Department of Energy

National Nuclear Security Administration

Nevada Site Office

P.O. Box 98518, M/S 505

Las Vegas, NV 89193-8518

U.S. Department of Energy

National Nuclear Security Administration

Nevada Site Office

Technical Library

P.O. Box 98518, M/S 505

Las Vegas, NV 89193-8518

U.S. Department of Energy

2 (electronic)

National Nuclear Security Administration

Nevada Site Office

Nuclear Testing Archive

Public Reading Facility

P.O. Box 98518, M/S 400

Las Vegas, NV 89193-8518

U.S. Department of Energy

1 (electronic)

Office of Scientific and Technical Information

Post Office Box 62

Oak Ridge, Tennessee 37831-0062 
Distribution List (continued)

\section{Bechtel Nevada}

Max Dolenc

Bechtel Nevada

P.O. Box 98521, M/S NSF080

Las Vegas, NV 89193-8521

Environmental Management Library

Bechtel Nevada

P.O. Box 98521, M/S NLV094

Las Vegas, NV 89193-8521

Steve Nacht

Bechtel Nevada

P.O. Box 98521, M/S NSF083

Las Vegas, NV 89193-8521

Stuart Rawlinson

Bechtel Nevada

P.O. Box 98521, M/S NTS416

Las Vegas, NV 89193-8521

Dan Tobiason

Bechtel Nevada

P.O. Box 98521, M/S NTS416

Las Vegas, NV 89193-8521 